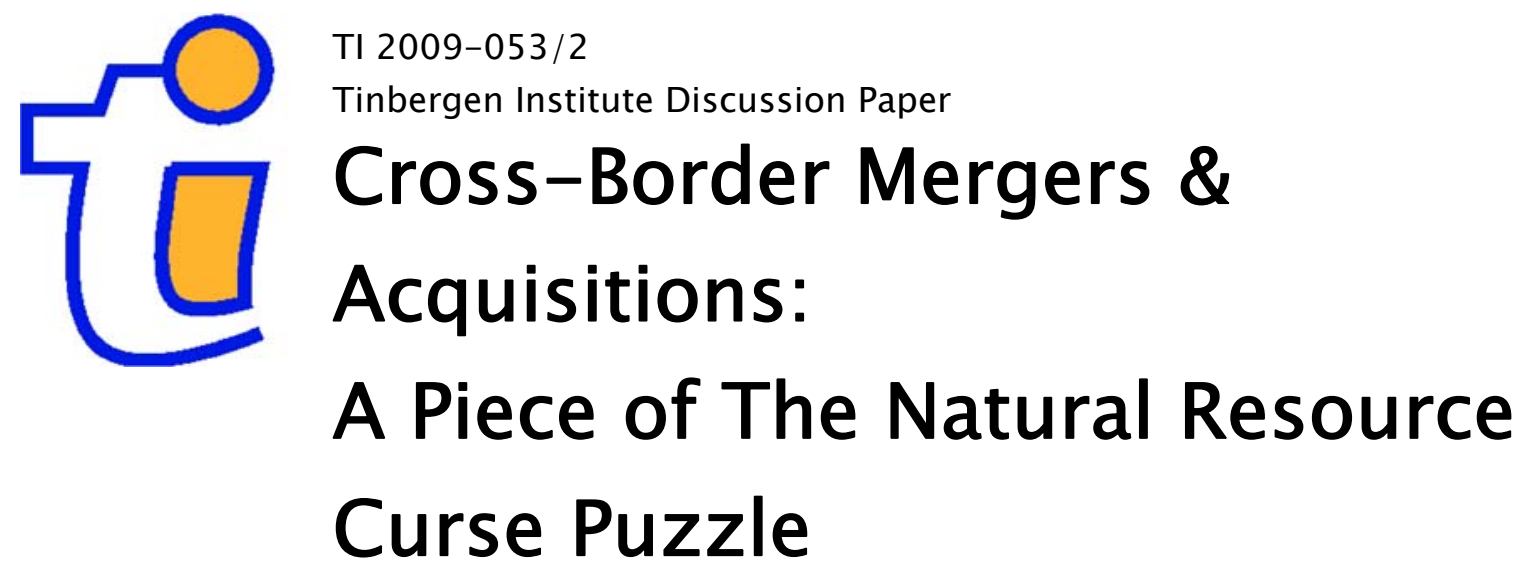

Julia Swart ${ }^{1}$

Charles van Marrewijk²

' Erasmus University Rotterdam, and Tinbergen Institute;

2 Utrecht University. 


\section{Tinbergen Institute}

The Tinbergen Institute is the institute for economic research of the Erasmus Universiteit Rotterdam, Universiteit van Amsterdam, and Vrije Universiteit Amsterdam.

Tinbergen Institute Amsterdam

Roetersstraat 31

1018 WB Amsterdam

The Netherlands

Tel.: +31(0)205513500

Fax: $+31(0) 205513555$

Tinbergen Institute Rotterdam

Burg. Oudlaan 50

3062 PA Rotterdam

The Netherlands

Tel.: + $31(0) 104088900$

Fax: $+31(0) 104089031$

Most TI discussion papers can be downloaded at http://www.tinbergen.nl. 


\title{
Cross-border mergers \& acquisitions: a piece of the natural resource curse puzzle
}

\author{
JULIA SWART ${ }^{*}$ \\ Tinbergen Institute \\ and \\ CHARLES VAN MARREWIJK \\ Utrecht University
}

August, 2009

WORK IN PROGRESS

\begin{abstract}
We combine the resource curse literature with the literature on cross-border mergers and acquisitions (M\&As) to investigate two hypotheses, namely (i) natural resources wealth: countries with a comparative advantage in natural resources attract more M\&As in natural resource intensive sectors and (ii) natural resources dependency: countries with a high natural resources dependency attract fewer M\&As in all sectors. Using the Thomson dataset we test these hypotheses for a sample of 49 African and Latin American countries in the period 1988 - 2007. To test these hypotheses we disaggregate the data in sectors intensive and not intensive in natural resources. We emphasize the distinction between resource dependency and wealth. Both hypotheses were confirmed by our findings. Thus, resource dependency has a 'crowding out' effect on M\&As in all sectors, and natural resources wealth has a 'crowding in' effect on M\&As in sectors intensive in natural resources.
\end{abstract}

JEL classification: F23; Q56

Keywords: Gravity Equation; Mergers and Acquisitions; Natural Resources; Resource Curse.

\footnotetext{
* Corresponding author; Tinbergen Institute, room H9-12 Erasmus University Rotterdam, PO Box 1738, 3000 DR Rotterdam, the Netherlands; swart@tinbergen.nl. We would like to thank Henri de Groot, Rick van der Ploeg, Jean-Marie Viaene and the seminar participants of the Tinbergen Institute, the Utrecht University and the Kingston University London for useful comments and suggestions. Finally, we would also like to thank Kirk Hamilton and Giovanni Ruta, from the World Bank, for providing 'unpublished World Bank data' on natural wealth, which was crucial for this research project.
} 


\section{Introduction}

The rapid increase of foreign direct investment (henceforth FDI) flows in the past 20 years has sparked a growing interest in the literature and in the policy field to better understand the determinants and impact of these flows. Remarkably, not many studies focus on the most important component of FDI flows for developing countries: crossborder mergers and acquisitions (henceforth M\&As). ${ }^{1}$ This lack of interest in developing countries might be caused by the small role they play either as a target or as acquirer of M\&As (see Unctad, WIR 2007). As a share of GDP, however, the role of M\&As for many developing nations is comparable to that of many developed nations. This is illustrated for Africa and Latin America in comparison to a selection of OECD nations in Figure 1 for the period 2001-2006, both from an acquiring and target perspective. ${ }^{2}$ In 2006, for example, from a target perspective M\&As relative to GDP were 3.4\% for Latin America and 2.4\% for Africa, which is higher for both regions than for Germany $(2.3 \%)$, Spain $(2.2 \%)$, or the United States $(2.2 \%)$. As acquirers, Latin American and African economies still lag behind in M\&A deals (Figure 1b). In 2006, acquiring M\&As relative to GDP did not reach 1\% for either region, compared to, for example, $4.7 \%$ for France.

We analyze the determinants of M\&As for Africa and Latin America using recent empirical and theoretical developments in the literature. We focus attention on the role of natural resources ${ }^{3}$ as a driving force of M\&As in trying to resolve a piece of the 'natural resource puzzle'. The effect of natural resources on FDI is one of the channels between natural resources and economic growth. Nonetheless, the direction of this effect is ambiguous in the empirical literature (see section $2 a$ ).

\footnotetext{
${ }^{1}$ The share of M\&As in FDI varies from year to year around 70-80\%, see Brakman, Garretsen, and van Marrewijk (2007).

${ }^{2}$ Included African countries: Egypt, Ghana, Kenya, Libya, Morocco, Nigeria, Senegal, South Africa, Tanzania, Tunisia, Uganda, Zambia and Zimbabwe. Included Latin American countries: Argentina, Bolivia, Brazil, Chile, Colombia, Costa Rica, Dominican Republic, Ecuador, Guatemala, Mexico, Peru, Uruguay, and Venezuela.

${ }^{3}$ Throughout this paper when we refer to natural resources we are also considering primary goods.
} 
Figure 1-Mergers and acquisitions relative to GDP, 2001- 2006

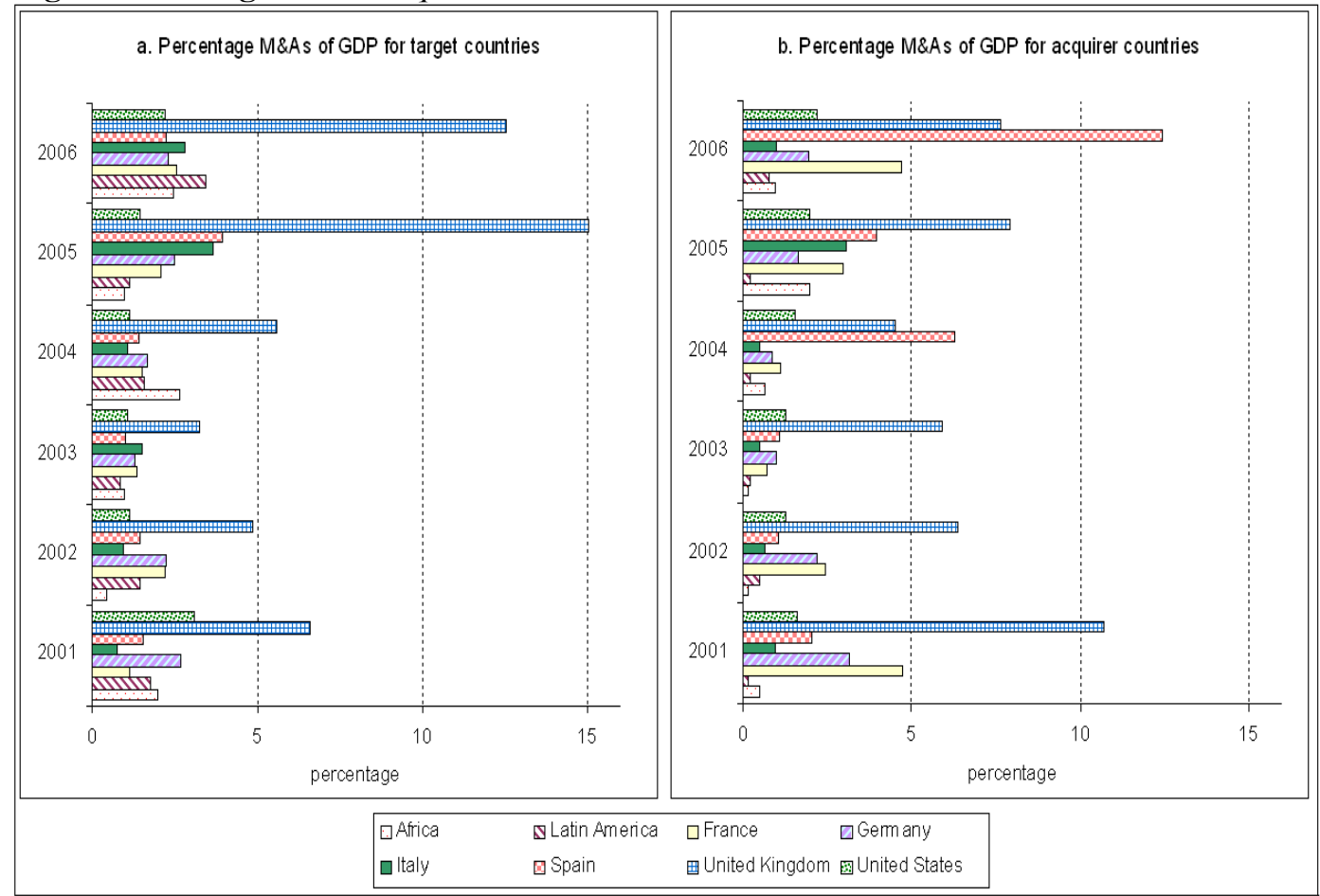

Source: Own calculations; based on data from Unctad - WIR(2007), and IMF - WEO2007.

Additionally, the relation among 'natural resources' and FDI for developing countries is relevant from a policy point of view. FDI has a positive role on economic performance, which has been extensively discussed in the literature (Borensztein, de Gregorio and Lee, 1998; Haskel, Pereira and Slaughter, 2007; Hausmann and Fernández-Arias, 2000). ${ }^{4}$ In particular, FDI could be an important source of diversification of economic activities, helping the rich resource economies become less dependent on only one or a few commodities to generate their growth. ${ }^{5}$ The diversification can create linkages and spillovers with other sectors of the economy, stimulating the growth and development of the nations receiving FDI flows.

\footnotetext{
${ }^{4}$ Evenett (2003) explores specifically the economic impact of M\&As. He shows that theoretically it is not clear whether this economic impact will necessarily be positive. Consumers benefit with the reduction in prices and increase in the variety and quality of products as a result of economies of scale and scope brought by M\&As. However, this is counterbalanced by the increase in market power from the firms, which has a negative anticompetitive effect.

${ }^{5}$ Dependence on a few commodities is one of the explanations for the resource curse. Volatility of commodity prices can generate cycles of raising or decreasing revenues because natural resources have a low price elasticity of supply. Moreover, this dependency can lead to lower growth due to the voracity effect. An increase in the price of a common stock of resources can lead to rent seeking as opposed to investment (van der Ploeg, 2006).
} 
More generally, understanding the role played by natural resources on M\&A inflows in developing countries is insightful. Sectors such as metal mining are notably the main attractors of M\&As to Latin America and Africa (see section 4 for details). Moreover, it is an ongoing debate in the resource curse literature, see section $2 \mathrm{a}$.

We are motivated by the contradictory results encountered in the empirical literature in relation to the impact of 'natural resources' on FDI. A few papers (see section 2a) show that 'natural resources' have a positive influence on FDI inflows. However, Gylfason (2004) finds a negative influence. A reason for this lack of consensus is a combination of the choice of a 'natural resources' variable and an aggregation problem. Therefore, we will disaggregate the data in sectors intensive in natural resources and sectors not intensive in natural resources. We expect to find a different coefficient for "natural resources' depending on the measure used. Specifically, we test two hypotheses:

\section{Hypothesis 1: Natural Resources Wealth}

Countries with a comparative advantage in natural resources, ceteris paribus attract more M\&As in sectors intensive in natural resources.

\section{Hypothesis 2: Natural Resources Dependency}

Countries with a high dependency in natural resources, ceteris paribus attract fewer M\&As in all sectors.

We base the first hypothesis on the fact that M\&As are more likely to occur in sectors where the target country has a comparative advantage. ${ }^{6}$ Many developing countries have a comparative advantage in natural resources, which, e.g., can be measured by natural resource abundance. Therefore, we expect wealthier countries in natural resources to attract more M\&As within sectors that use these resources intensively. The second hypothesis is motivated by theoretical findings from the resource curse literature. These theoretical findings associate resource dependency with external market instability. The external market instability causes a negative effect on FDI inflows. We will discuss both aspects in more detail in the next section.

\footnotetext{
${ }^{6}$ As we will discuss later Brakman et al. (2008) show that M\&As towards target countries are directed to the sectors where the countries have a high comparative advantage.
} 
To test the two hypotheses we base our econometric analysis on a gravity model specification. Using a zero-inflated model we compare three regressions: first with all the data; second with data restricted to M\&As in natural resources intensive sectors; and third with data restricted to M\&As in sectors not intensive in natural resources. We give special attention to 'natural resources' as a determinant of M\&As.

The structure of the remainder of this paper is as follows. Section 2 presents an overview on the resource curse literature and on the current literature on FDI, focusing on M\&As. Section 3 deals with the empirical model specification, description of the variables used and the econometric methodology. In Section 4 the data base on M\&As is discussed and we present descriptive statistics. Section 5 covers the estimation results and robustness checks. In Section 6 concluding remarks are given.

\section{Theoretical Framework}

\section{2 a Resource Curse}

There are many examples of natural resource rich countries which have not benefited from their wealth in terms of economic development. Oil-rich Nigeria, for example, has a stagnating income per capita level since 1970, while the poverty rate has increased from 36 percent in 1970 to 70 percent in 2000. In this period the number of poor people has risen from roughly 19 to 90 million (Sala-i-Martin and Subramanian, 2003). Similar experiences are discussed in the literature. This phenomenon is referred to as the 'resource curse'. ${ }^{7}$ There is, however, no agreement as to whether natural resource abundance is indeed a curse. There are countries, e.g., Botswana and Norway, which have made good use of their natural resource wealth. These different experiences are the result of many channels through which natural wealth affects growth and development.

The different channels from natural wealth to growth imply that the income generated by natural resources does not necessarily result in positive growth. Growth will only result if the wealthy country in natural resources adopts policies to manage its income in a productive and efficient manner. A healthy environment for good policies is therefore

\footnotetext{
${ }^{7}$ See, for example, Mehlum et al. (2006), Robinson et al. (2006), and Gylfason (2004).
} 
necessary. Good institutions, existence of reliable rule of law and transparency are a few conditions for a 'resource blessing' (van der Ploeg, 2006). In other words, natural resource abundance does not determine per se the economic benefits or harms that it will bring. The overall result is determined by the use made of these resources and by the implications of these actions on other economic activities. Therefore, although there is disagreement over the benefits/ harms of natural wealth, there is evidence that institutional quality and trade openness, for example, improve the chances of a resource blessing instead of a curse (van der Ploeg, 2006).

Gylfason (2004) discusses five channels of transmission from natural resource abundance to economic growth. One of them is the "Dutch disease and foreign capital". This is the channel we focus on this research. Given the considerable fluctuation of raw materials prices, countries with a higher export dependency on natural resources are more inclined to suffer from exchange rate volatility. This creates uncertainty in the external market not only for trade but also for foreign investment.

In support of the "Dutch disease and foreign capital" channel, Poelhekke and van der Ploeg (2007) show that volatility is one of the most important channels through which natural resources affect growth in a negative way. An important point of this argument is that it is not natural resource abundance that tends to generate more volatility, but the dependence on natural resource revenues. Moreover, Poelhekke and van der Ploeg (2007) indicate that countries that experience more volatility of commodity prices receive less FDI.

Based on these perspectives, we expect natural resource dependency to have a negative impact on FDI inflows. This result motivates our second hypothesis that countries which are more dependent on natural resources experience fewer inflows of M\&As into all sectors. By disaggregating the data we check whether the intensity of the effect of natural resource dependency on M\&As depends on the target sector of M\&A.

In general, literature on the analysis of the determinants of FDI (particularly, M\&As), e.g., di Giovanni, 2005; Hijzen et al., 2008; Brakman et al., 2008, do not consider 
natural resources as a factor that may drive such flows. Common regressors are: size of the domestic market, distance between the home and target market and institutional variables (such as financial and trade openness). Studies that take into account 'natural resources' (Asiedu, 2003; Deichmann et al, 2003; Onyeiwu and Shrestha, 2004) do not make a distinction between the sectors to which the investment flows are directed and often do not make a distinction between natural resource abundance and dependency.

Moreover, the empirical literature that controls for 'natural resources' show both a negative and a positive impact of 'natural resources' on FDI inflows. Onyeiwu and Shrestha, 2004; Deichamn et al., 2003 and Jensen, 2003 found a positive coefficient for 'natural resources'. Onyeiwu and Shrestha (2004) use a panel data for 29 African countries between 1975 and 1999 to analyze the determinants of FDI. The authors measure natural resource availability by the percentage of fuel exports to total exports. Onyeiwu and Shrestha find a positive and significant link between this natural resource availability variable and FDI.

Deichmann et al. (2003) analyze the determinants of FDI for Eurasia transition economies. In particular Deichmann et al. assess the impact of resource scarcity on the value of FDI per capita. Resource scarcity is measured via an index. The index equals 0 if a country is poor in natural resources, 1 if it is moderate and 2 if rich. The availability of this index is restricted to a few transition economies (see de Melo et al., 1997). This index measures the diversity of natural resources in a country. Thus the index captures whether self sufficiency in natural resources favours the attraction of FDI. Deichmann et al. show that resource scarcity has a negative effect on FDI.

A more comprehensive study was performed by Jensen (2003) who used both crosssectional and panel regressions analysis to analyze the forces of attraction of FDI for 114 countries. Although the focus of Jensen's paper is on the relationship between democratic governance and inflows of FDI, natural resource dependency is also used as a control variable. Their study showed that natural resource dependency has a positive and significant impact on FDI. 
The abovementioned studies show that natural resources have a positive influence on FDI. The definition of 'natural resources', however, varies per study, making it difficult to compare the results. Moreover, none of these papers use a gravity model approach, a standard framework to measure inflows of FDI. They also do not discuss the many zero observations associated with FDI. The exclusion of zero values is a common mistake in empirical work. Alternative methods are available to take this data into consideration. It relies on a gravity model approach (see Silva and Tenreyro, 2006 and Garita and van Marrewijk, 2008).

Gylfason (2004), on the other hand, shows that increased dependency on natural resources has a negative effect on FDI inflows. Considering the Arab world experience, Gylfason shows that natural capital "crowds out" foreign capital. In addition, for a sample of 85 countries, Gylfason finds that being rich in natural resources has a negative impact on openness to FDI.

The lack of consensus in the literature can be explained by three major elements. First, there is a loose interpretation and use of the term "natural resource abundance". The resource dependency variable (measured by the ratio of primary exports to total exports) is not a perfect proxy for natural resource abundance (Brunnschweiler, 2008). Moreover, a few studies not only use exports of natural resources as a proxy for natural resources abundance, as they also restrict the measure to oil exports or mineral exports. The problem in using resource dependency is to then claim an association between natural resources abundance and FDI. The correct conclusion is, instead, between resource dependency and FDI (as we will show, resource dependency has a negative impact on M\&As, regardless of the sector). ${ }^{8}$ Therefore, care must be taken in the use and interpretation of the chosen variable.

\footnotetext{
${ }^{8}$ Given our sample of countries we compare the measure of natural wealth from the World Bank (unpublished estimates) with the measure of resource dependency used in our estimation procedure. The correlation between these two variables turned out to be low. If we take the level of natural wealth, the correlation with resource dependency is 0.08 (for the year 2000). A closer look at the data makes it evident that there is no straightforward connection between them: there are countries very rich in natural resources with a low resource dependency (Brazil, for example), and countries relatively less rich in natural resources but highly dependent on exports of natural resources (ex: Cote d'Ivoire and Ghana). The correlation is higher if we consider natural wealth per capita instead, 0.23. Still, the measures are not interchangeable, and the interpretation of the results has to be consistent with the measure used.
} 
A second reason for the lack of consensus in the literature is, as we have already noted, the exclusion of the zero-values flows of FDI. The fact that two countries have no flows of FDI is important information, and should not be excluded from the dataset. This exclusion biases the results.

Finally, a third reason for the different results in the literature for 'natural resources' as a determinant of FDI is the aggregation of the data. To the best of our knowledge the present paper is the first to disaggregate the data into (i) natural resource intensive sectors and (ii) non intensive in natural resources sectors to explore the determinants of M\&As. The disaggregation of the data shows that resource dependency and natural wealth have different effects on M\&As inflows (see section 5). The result depends on the sector of the target firm.

\section{$2 b$ Cross-border Mergers and Acquisitions}

International trade economists have linked the theory on multinationals with the international trade theory. These economists analyze a firm's motivation to serve a foreign market via foreign production or via exports. There are disadvantages (e.g. language and customs differences and legal and institutional costs) and advantages (ownership, location, and internalization) with producing in a foreign country. The three advantages just mentioned were proposed by Dunning; the O.L.I. framework. These advantages motivate a firm to serve a foreign country through direct investment instead of trade (see Markusen, 1995 for an overview).

The O.L.I. framework provides two options for the firm: exports or direct investments. There are, however, other options available to the firm, such as licensing and joint venture. Additionally, FDI is broadly divided into two categories: greenfield investments and M\&As. The latter constitutes the biggest share of total FDI (Brakman et al., 2008). The predominance of M\&As flows led to the recent development of a strand in the literature particularly concerned with the explanation of the determinants of M\&As. According to Neary (2007), the Industrial Organization (I.O.) literature proposes that mergers are motivated by efficiency gains. These gains are a consequence, for example, of technological transfer and managerial synergies. A second motive for 
mergers is a strategic one, by changing the market structure. A merger or acquisition implies the removal of a competitor from the market, resulting in a profit increase for the remaining firms. The strategic motive has been illustrated under a Cournot competition model (Farrell and Shapiro, 1990 and Perry and Porter, 1985). Is it shown that under such a model mergers may arise as the best outcome.

The drawback of such analyzes is their partial equilibrium framework, which excludes the interaction between markets, such as good and factor markets. Neary (2007) made a major contribution by combining elements from the I.O. literature into the theory of international trade. The author builds an oligopoly model in a general equilibrium framework (GOLE model). One of the important elements from this approach is the possibility of analyzing how trade patterns influence M\&As flows.

In the GOLE model, differences in costs between home and foreign firms and the number of firms in the target and the acquirer countries, determine whether there is a gain in conducting a merger. If the profit of the acquiring firm is higher than the initial (pre-merger) profits of both the target and the acquiring firms then merging is the best strategy for the acquiring firm. Moreover, a merger implies the taking over of the target firm, resulting in a reduction of the number of firms in the market and in an incentive for further takeovers. Thus, another important element from this approach is the theoretical foundation for M\&A waves.

M\&A waves are an empirically verifiable fact. Either taking the number of deals or the value of deals a simple plot by time shows periods of increasing M\&As and periods of decreasing M\&As (see for an illustration Brakman et al., 2007). In the $20^{\text {th }}$ century there were five merger waves, with the last case occurring between 1995 and 2000. With our particular dataset, covering the periods 1988 until 2007 three waves are present: the end of the fourth wave (1988-1990), the fifth wave (1995-2000) and the sixth wave, which started in $2003 .^{9}$

\footnotetext{
${ }^{9}$ In addition to the existence of waves it is also a stylized fact that the scale of M\&As are much larger in more recent waves than in previous one (Evenett, 2003 compares the wave from the 90s with the one from the $80 \mathrm{~s}$, showing that the latest is about five times larger in real terms than its predecessor).
} 
Figure 2 - Distribution of number and value of $M \& A s$ between the five most active target countries in Latin America and Africa.

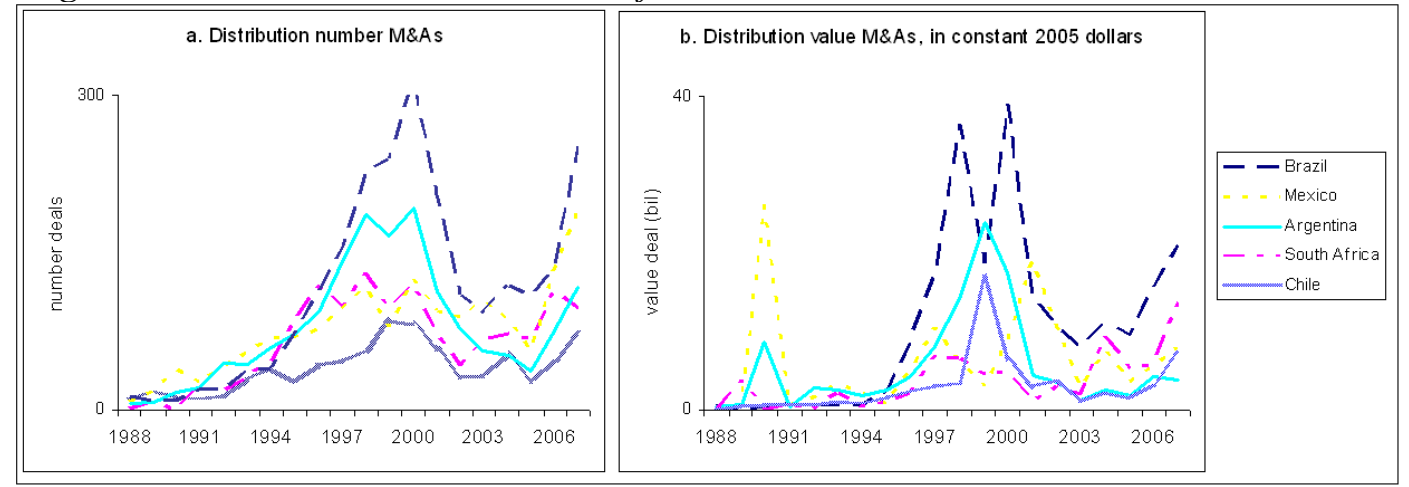

For the data we collected (see section 4 for details), the majority of M\&As towards Latin America and Africa, either in terms of number or in terms of value of the deals, is concentrated in a few countries, notably, Brazil, Argentina, Mexico, South Africa and Chile. For these five countries (see Figure 2) M\&As inflows are increasing in the period starting around 1995 until 2001. After 2001, there is a decline of M\&As inflows, with a subsequent increase in more recent years, around 2005. This pattern gives an indication of the waves reported in the recent theory of M\&As. It is also in accordance to the wave periods described by Brakman et al. (2007).

Brakman, Garretsen et al. (2008) test two implications of Neary's model for five OECD countries. First, they test whether differences in cost affect individual cross-border M\&As. Neary's model implies that if a firm has a cost advantage, then it is profitable to merge with the highest cost firm. Brakman, Garretsen et al. use the Balassa index as a measure for cost advantage. For the case that the sample of countries is in the position of acquirers, the findings confirmed the theoretical prediction of Neary's model. The authors find a positive relation between comparative advantage in a sector and the number of acquiring firms.

When the countries are in the position of targets again the finding is that they are in sectors with a comparative advantage. The authors name the latter finding the "target paradox", which they explain by allowing firm heterogeneity in a multi-country extension of the GOLE model. This finding motivates our first hypothesis. Many Latin American and African countries have a comparative advantage in natural resources. 
Therefore, the result from Brakman, Garretsen et al. (2008) indicates that these countries are expected to receive M\&As in sectors that use natural resources intensively.

The second implication of Neary's model, which Brakman, Garretsen et al. (2008) test, is whether M\&A waves help explain M\&As. The authors find that either taking the five OECD countries as acquirers or as targets, there is a positive global wave effect of M\&As. This confirms the findings in Neary's model.

In addition to Brakman, Garretsen et al. (2008), other authors (Di Giovani, 2005; Hijzen et al., 2008; Brakman, Garita et al., 2008 and Garita and van Marrewijk, 2008) use a gravity-type framework to analyze M\&As flows. Di Giovani (2005) uses a gravity model to test the impact of financial markets deepness in the acquiring countries on M\&As. Although the author bases the analysis on the gravity model, by considering a log-linear form the inclusion of the zero flow values is not feasible. ${ }^{10}$ The problem is minimized by adopting a two stage Tobit model. An alternative is to include the zero observations in the estimation procedure (see section 3 ).

Hijzen et al. (2008) adopt a gravity model to analyze the role of trade costs in determining M\&As. The authors use data for 23 OECD countries and disaggregate the data by sectors. In particular, Hijzen et al. focus on manufacturing industries and separate the M\&As between horizontal and non-horizontal at the 4-digit SIC code classification. The authors estimate the model through a negative binomial regression, an approach we will discuss later. This approach has the advantage of allowing the zero observations data and of controlling for possible dispersion in the data.

Finally, two recent papers use the same econometric approach (zero-inflated model) as the one we adopt in this paper (Brakman, Garita et al. 2008; and Garita and van Marrewijk, 2008). Both papers analyze the determinants of M\&As flows. The reason for working with a zero-inflated model when dealing with M\&As flows will become clearer in the next section.

\footnotetext{
${ }^{10}$ To overcome this problem some authors use $\ln ($ value +1$)$ instead of $\ln$ (value) as the dependent variable in the Tobit estimations. However, this leads to inconsistent estimates (Silva and Tenreyro, 2006).
} 


\section{Empirical Model}

We base our empirical model in a gravity equation framework, originally introduced in economics in the trade literature. The gravity equation can be derived from different models, such as Ricardian, Hechscher-Ohlin, and increasing returns to scale. ${ }^{11}$ In its simple form, the gravity model for trade states that trade flows among two countries is a function of the size of each country (measured in terms of GDP) and the distance among the countries. GDP of both countries affect trade flows positively, whereas distance is negatively proportional to trade flows. We can describe this simple form as:

$$
T_{i j}=\alpha_{0} Y_{i}^{\alpha_{1}} Y_{j}^{\alpha_{2}} D_{i j}^{\alpha_{3}} \eta_{i j}
$$

where $T_{i j}$ is trade flows among country $i$ and country $j ; Y_{i}$ and $Y_{j}$ are GDP of country $i$ and $j$, respectively, $D_{i j}$ is distance among the two countries, and $\eta_{i j}$ is an error term.

For the purpose of the research herein, we incorporate additional control variables from theoretical literature on M\&As: wave and transaction cost. The latter variable is measured by a dummy of common language between target and acquirer countries, and by a dummy variable of past colonial relation between target and acquirer countries. We also incorporate in the model variables which are more broadly used in the empirical literature to explain the determinants of M\&As: GDP per capita of target and acquirer countries and institutional variables. The latter encompasses three variables: transparency, trade openness and financial openness. Finally, we control for 'natural resources'. We estimate whether 'natural resources' drive inflows of M\&A, using 20 years data for a set of countries from Latin America and Africa (see appendix A for a list with the countries names).

Considering these additional control variables, the gravity model for this research is as follows:

$$
M_{i j t}=\alpha_{0} Y_{i t}^{\alpha_{1}} Y_{j t}^{\alpha_{2}} Y p c_{i t}^{\alpha_{3}} Y p c_{j t}^{\alpha_{4}} D_{i j t}^{\alpha_{5}} R_{i t}^{\alpha_{6}} C_{i t}^{\alpha_{7}} C_{j t}^{\alpha_{8}} C_{t}^{\alpha_{9}} M_{i j(t-1)}^{\alpha_{10}} \eta_{i j t}
$$

\footnotetext{
${ }^{11}$ See Evenett and Keller (2002) for a test on the theories in international trade that are behind the success of the gravity equation.
} 
where $M_{i j r t}$ refers to the number of M\&As between countries $i$ (target) and $j$ (acquirer) and sector $r$ at time $t$. Using this notation, we have considered above that M\&As are not only a function of size of the countries, and distance among them, but also of the GDP per capita from the target $\left(Y p c_{i}\right)$ and from the acquirer $\left(Y p c_{j}\right)$, control variables of the target country $\left(C_{i}\right)$, control variables of the acquirer country $\left(C_{j}\right)$, common control variables $\left(C_{t}\right)$, natural resources $\left(R_{i}\right)$ and previous global M\&As $\left(M_{i j(t-1)}\right) .^{12}$

The control variables for the target countries are: a transparency measure, ranging from 0 (highly corrupt) to 10 (highly clean), a measure of trade openness and one of financial openness and dummies for regions. ${ }^{13}$ The control variables for the acquirer countries are: a measure of trade openness and one of financial openness and dummies for regions. The common control variables are: a dummy for common language between target and acquirer countries, a dummy for past colonial relation between target and acquirer countries and dummies for year. ${ }^{14}$ Appendix $\mathrm{C}$ describes the sources, definition and availability of the data.

As for the measure of 'natural resources', we use two variables: natural resource dependency (measured as percentage of exports of natural resources to GDP) and natural wealth. We use the natural resource dependency measure to evaluate M\&As in sectors not intensive in natural resources as well as in sectors intensive in natural resources. The main reason for this choice is that we expect countries dependent on natural resources to receive less M\&As in all sectors (see section 2a and Hypothesis 2). According to Gylfason (2004) and Poelhekke and van der Ploeg (2007) if the weight of natural resources revenue on an economy is too high then this economy is much more vulnerable to changes in commodities prices, creating uncertainty for the investors. Therefore, following the literature on volatility of commodity prices and the Dutch

\footnotetext{
${ }^{12}$ The motivation to include a global wave variable in our regression model comes from the positive global wave effect of M\&As found in Brakman, Garretsen et al. (2008), as predicted in Neary's GOLE model.

${ }^{13}$ Appendix B presents a list with the regions considered.

${ }^{14}$ Baldwin and Taglioni (2006) show that the inclusion of national and year dummies can prevent bias estimates due to omission of terms in the estimation procedure which are part of the formal model of the gravity equation for trade flows. Due to our large number of acquirer countries, we have used instead dummy for regions to control for regional fixed effects.
} 
disease, the measure of natural resource dependency (embracing all primary products) is a good measure to evaluate the impact of 'natural resources' on M\&As.

For sectors intensive in natural resources, our measure for 'natural resources' is natural resources dependency and natural wealth. This latter variable gives an indication of a comparative advantage in sectors which use these inputs intensively. Having a comparative advantage in natural resources is an important attracting force of M\&As in sectors intensive in natural resources (see Brakman, Garretsen et al., 2008). The variable of natural wealth is only available for three years, 1995, 2000 and 2005. To overcome this problem we consider the same value for 1993, 1994, 1996 and 1997 as of 1995 . We take the same value for 1998, 1999, 2001 and 2002 as the value from 2000. And, the same value for 2003, 2004, 2006 and 2007 as the value from 2005. This is a good approximation, since a measure such as natural wealth is not expected to change significantly from one year to another.

Considering the case where the dependent variable is the value of the flows, Silva and Tenreyro (2006) propose solving a model such as the one given in equation (2) using a pseudo-maximum-likelihood technique (PML). Specifically, the authors suggest the Poisson PML, which solves the problem of inconsistency in the presence of heteroskedasticity and allows dealing with the zero values for M\&As flows. The problem with the Poisson model is that it assumes equidispersion of the data, which is not a realistic assumption for most datasets. If this assumption does not hold the data is likely to be correlated, affecting the standard errors estimates of the parameters and the model fit (Hilbe, 2007). Silva and Tenreyro take this into account by basing the inference on a robust covariance matrix. An alternative to deal with over-dispersion is to use one of the variants of the negative binomial in place of the Poisson.

For the specific case where the dependent variable is a count, there are many possible estimation procedures available to estimate the model (see Hilbe, 2007). If there is however a high percentage of zero counts, the Poisson and the Negative Binomial distribution tend to predict less zero counts for a given mean than the observed ones. To 
overcome this problem a zero-inflated model or a hurdle ${ }^{15}$ model should be used. The difference between these two is that the former uses both binary and count processes to model the zero counts, whereas the later separates the modelling of zeros from the modelling of counts (Hilbe, 2007).

To estimate M\&As flows the zero-inflated model is a better choice than the hurdle model. The reason is that it is not realistic to have a 'zero barrier' (as in the hurdle model) that must be crossed in order to enter a stage of positive counts. In this scenario, once this barrier is crossed the possibility of having a zero flow is not observable anymore. For the M\&As data there are, for example, years for which a certain country has a positive count of $M \& A$ and in other years it faces either zero or positive outcomes. The zero-inflated model allows modelling these types of situations.

There are two varieties of the zero-inflated model: the zero-inflated Poisson (ZIP) and the zero-inflated negative binomial (ZINB). As we show in section 5 the model that best fits our data is the latter, since it takes into account two characteristics of it: overdispersion and excessive zero counts.

Zero-inflated models are two-part models. The first part is a binary model and the second part a count model. The binary model can be estimated using either a probit or a logit. For the count model (including zeros) the Poisson (PRM) or negative binomial (NBRM) regression can be used. For our particular application, we have two groups of countries, one for which there is always an outcome of zero, and another for which a non-negative outcome can occur with a non-zero probability. Thus, in the first part of the model, by means of a logit we model in which of these two groups a particular country belongs. The probability of zero and higher than zero are given respectively by:

$$
\begin{aligned}
& P\left(y_{i}^{*}=0 ; z_{i}\right)=\frac{\exp \left(z_{i} \gamma\right)}{1+\exp \left(z_{i} \gamma\right)}, \\
& P\left(y_{i}^{*}>0 ; z_{i}\right)=\frac{1}{1+\exp \left(z_{i} \gamma\right)},
\end{aligned}
$$

\footnotetext{
${ }^{15}$ Hurdle models are also referred as zero altered models.
} 
where $z_{i}$ are the inflated variables, which are the explanatory variables for the binary part of the model. The inflated variables may or not be the same as the explanatory variables for the count part of the model. In our framework we have no reason to believe that there are distinct variables explaining these two processes; therefore we consider them to be the same. ${ }^{16}$

The star superscript in the counts $\left(y_{i}^{*}\right)$ stands for the fact that the two groups are in practice unobserved. We observe the countries in the dataset which have a positive or zero counts for M\&As in the years analyzed. Given this data we can estimate the probabilities by proceeding to the count part of the model. This part consists of estimating, through a negative binomial regression, the probability of each count for those countries in the group with a non-zero probability of having a positive count (hereafter: active group). Since the group members are not completely observed, we have the following probabilities for the actual count of M\&As:

$$
\begin{aligned}
& P\left(y_{i}=0 ; x_{i}, z_{i}\right)=P\left(y_{i}^{*}=0 ; z_{i}\right)+P\left(y_{i}^{*}>0 ; z_{i}\right) f_{N B}(0), \\
& P\left(y_{i}=k ; x_{i}, z_{i}\right)=P\left(y_{i}^{*}>0 ; z_{i}\right) f_{N B}(k)
\end{aligned}
$$

where $f_{N B}$ is the density function of the negative binomial:

$$
f(y ; \mu, \alpha)=\left(\begin{array}{c}
y+1 / \alpha-1 \\
1 / \alpha-1
\end{array}\right)\left(\frac{1}{1+\alpha \mu}\right)^{\frac{1}{\alpha}}\left(\frac{\alpha \mu}{1+\alpha \mu}\right)^{y},
$$

with $\alpha$ being the over-dispersion parameter and $\mu$ the mean.

If $\alpha=0$ then the model reduces to the Poisson model, where the variance is equivalent to the mean. In the zero-inflated model, the over-dispersion parameter is an addition parameter to be estimated. We anticipate in stating that for our results, the overdispersion parameter is always significantly higher than zero. Since the over-dispersion

\footnotetext{
${ }^{16}$ An exception is the dummy for years in the estimation of the logit model. First we estimated the model with theses dummies included in both parts of the ZINB, but since they turned out to be highly insignificant in the logit model, we ran the regression again with this exclusion. Also, this exclusion did not represent any significant change in terms of coefficient values and significance level.
} 
parameter is significantly positive, we should use the negative binomial count instead of the Poisson. We also perform the suitable tests to identify the best model for our dataset. The result was always the ZINB. Therefore, we restrict to presenting these results later. First, however, we discuss the data and draw descriptive statistics.

\section{The Data}

4a Overview of the dataset

Given our interest in studying the determinants of M\&As in developing countries, we focus on countries from Africa and Latin America. We select countries with more than 5 million inhabitants in $2000 .{ }^{17}$ This criterion restricted our sample of countries to 33 African countries and 16 Latin American countries. This group of 49 countries is what we refer to as our selected group of countries. These countries are illustrated, in dark, under Figure 3.

Figure 3 - Sample of countries included in the dataset.

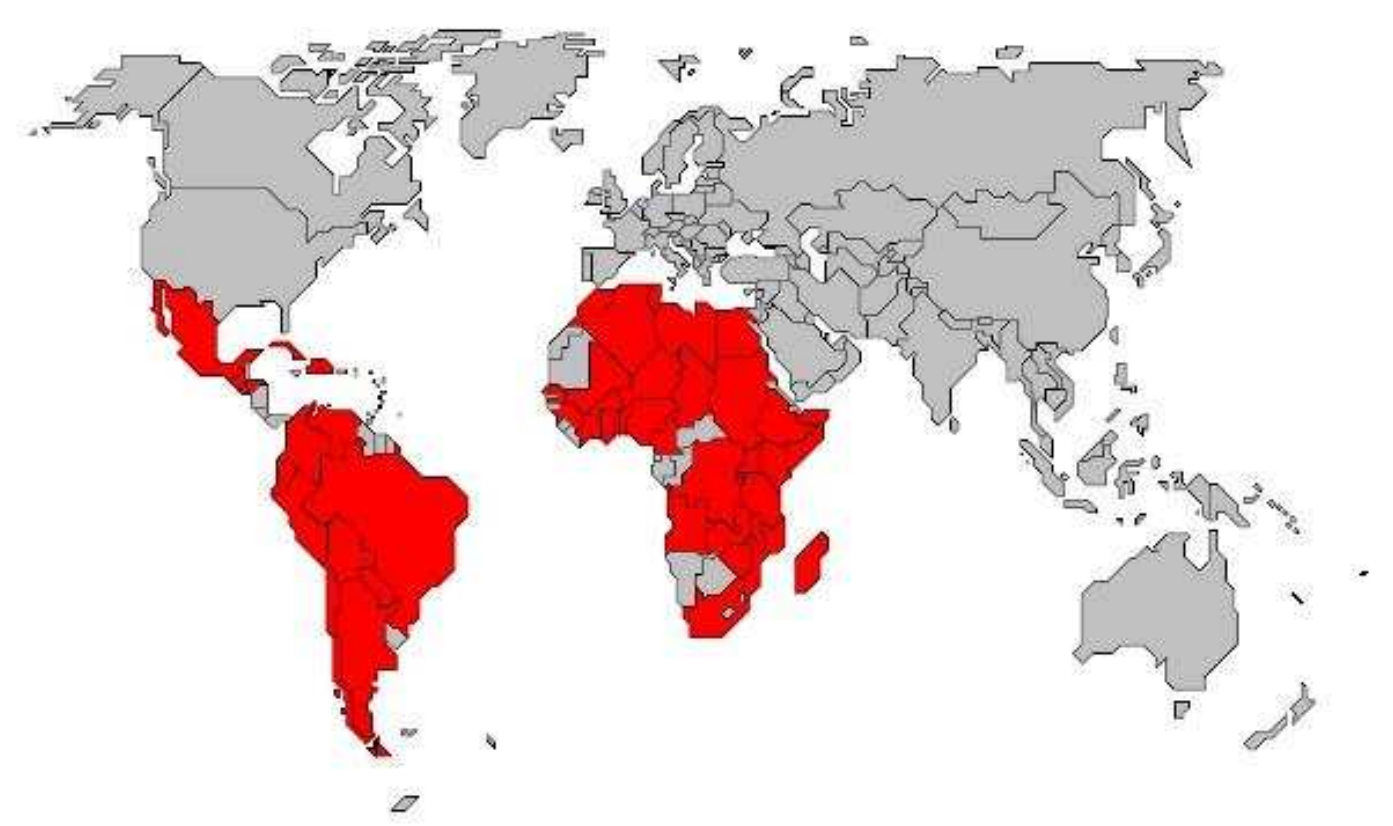

The database for cross-border M\&As used comes from Thomson Financial Investment Banking (henceforth: Thomson). Thomson collects data for all M\&As, providing detailed information, by industry, for over 220 countries. It collects data through

\footnotetext{
${ }^{17}$ Data source for population size was the World Bank, WDI.
} 
investigation of news, reports, among others. In this sense, Thomson provides very complete and updated data. For our purpose we restricted the data collection to the years between 1988 and 2007. Prior to 1988 Thomson focused in M\&As where the United States was involved. Therefore not all M\&As for countries other than the United States were incorporated in the dataset.

We followed Hijzen et al. (2008) and selected the data from Thomson based on announced date of transaction instead of effective date. By doing so we use all the data related to the intention to merge or acquire a foreign firm. Because we are interested in the determinants of M\&As from the point of view of the acquirer firms, every data that gives an indication of their interest to merge or acquire to a cross-border firm is a valuable information. Nonetheless, we excluded from our selection, the transactions which were marked with the followings status: "unknown", "rumor", "seeking buyer", "discontinued rumor" and "seeking buyer withdrawn". The reason for this exclusion is that first, we wanted to restrict to more reliable data. ${ }^{18}$ The second reason is that our focus is on the determinants of the acquirer firms to merge or acquire foreign firms, and not on the determinants of targets firms to accept or look for a deal. ${ }^{19}$ Given this criterion, we kept all data which had as status: "completed", "intended", "pending", "partially completed", "unconditional" and "withdraw". ${ }^{20}$ All of these categories give an indication of the interest to merge or acquire a foreign firm.

Table 1 - Data description: status of $M \& A$ deals

\begin{tabular}{l|c}
\hline \hline & Number \\
\hline \# of deals & 10,625 \\
Status completed/ partially completed & 8,050 \\
Status pending & 2,083 \\
Status intended & 184 \\
Status withdrawn/ intended withdrawn & 308 \\
\hline \hline
\end{tabular}

18 Thus the exclusion of data with status "rumor", "discontinued rumor" or "unknown".

${ }^{19}$ Thus the exclusion of "seeking buyer" and "seeking buyer withdrawn", which are related to the interest of the target firm to seek out a buyer.

${ }^{20}$ For an overview of the definitions of the status of transaction refer to Thomson's website: http://mergers.thomsonib.com/td/DealSearch/help/def.htm\#STATC 
The restriction of the dataset as described above left us with 10,625 observations for M\&As between 1988 and 2007 when our selected group of countries is the target. The majority of the deals had as status completed or partially completed $(75.8 \%)$, but there were also deals whose outcome was still pending (19.6\%) and others with status intended $(1.7 \%)$ and withdrawn or intended withdrawn $(2.9 \%)$ at the date of the collection of the data. These data are summarized in Table 1.

By grouping the countries in regions, the predominance of flows to Latin America is evident (see Figure 4). On average, $77 \%$ of the deals directed to Latin America and Africa between 1988 and 2007 were concentrated in the first region. This significant difference among the regions is particularly relevant for our econometric analysis. Having two groups with structural differences will help explaining the determinants of M\&As as set up by our model.

Figure 4-Distribution number of $M \&$ As between target regions.

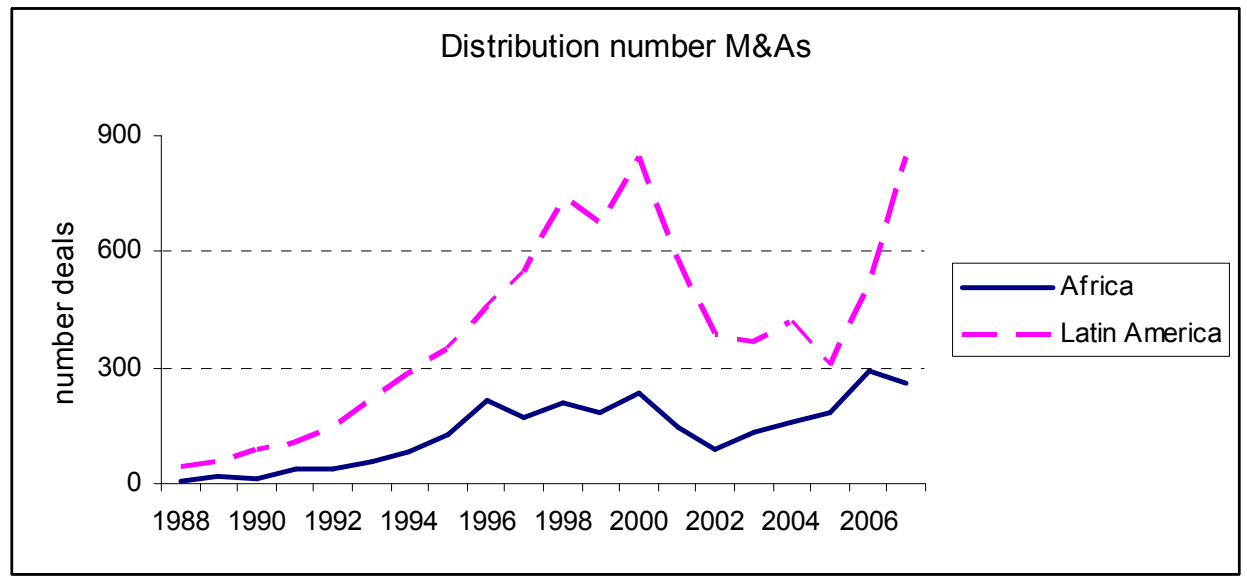

When Latin America and Africa are the target countries, then their acquirer firm is originally from a developed country in $74 \%$ of the cases. Also, contrary to what the theory of FDI predicts for flows among developed and developing countries, the majority of the M\&As deals in the period were horizontal (on a 2 digit SIC code sector level $^{21}$ ), around $60 \%$ when Latin America and Africa are targets. These flows were concentrated around the same sectors throughout the period analyzed.

\footnotetext{
${ }^{21}$ See appendix D for the 2 digit SIC sector groups.
} 
Figure 5 -Distribution number of M\&As by target 2 digit SIC code: percentage of main sectors over the total.

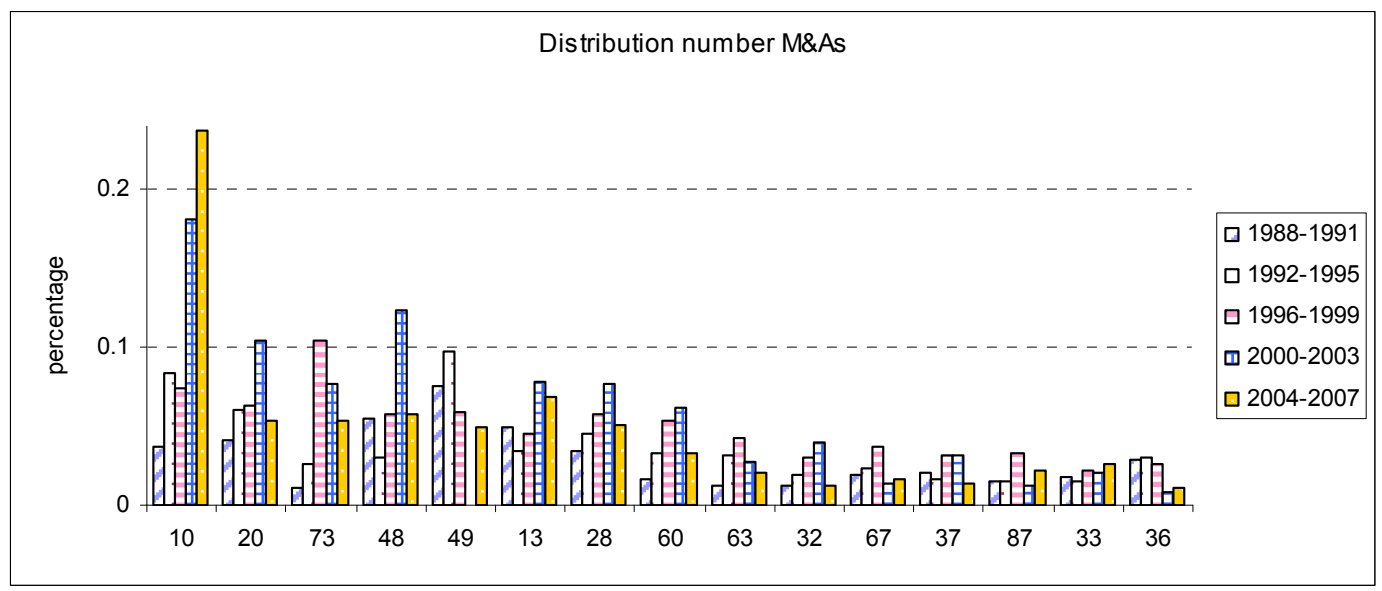

To illustrate the sector concentration of M\&As flows we grouped the data into a four years period. We analyzed the distribution of the flows for the 2 digit SIC code, taking the 15 sectors that have attracted more M\&As into account (see Figure 5). In terms of number of M\&As the two most important 2 digit sector for the entire period were 10 (metal mining) and 20 (food and kindred products). Another aspect shown in the figure is that the sectors with a higher participation in M\&As are similar in all of the five years groups considered. That is, it seems that both regions tend to attract M\&As in the same sectors throughout the time.

Disaggregating the data by regions, this concentration pattern around a few sectors throughout the years is preserved for both Africa and Latin America. Moreover, the concentration tends to be in the same sectors for both regions. This can be seen from Table 2, which shows the importance of each sector by rank of number of M\&As taking the whole period (1988-2007) into account. In order to construct the table we limited the sectors such that at least the 10 top sectors from each region would be included in the presentation. The table shows that for the 10 most important target sectors in terms of number of M\&As in Latin America and Africa, 7 of them are the same for both regions. Metal mining (sector code 10) has the highest number of M\&As in both Africa and Latin America. For Africa this sector accounted for 15.5\% of all deals announced, and for Latin America it represented 12.9\%. Another indication of concentration is that the 
13 sectors presented in the table correspond to approximately $70 \%$ of Africa's and Latin American's received M\&As.

Table 2 - Main target sector for M\&As in Latin America and Africa (1988-2007)

\begin{tabular}{l|cc|cc}
\hline \hline & \multicolumn{2}{|c|}{ Africa } & \multicolumn{2}{c}{ Latin America } \\
Sector & $\begin{array}{c}\text { Rank by } \\
\text { number }\end{array}$ & $\begin{array}{c}\text { \%of } \\
\text { total }\end{array}$ & $\begin{array}{c}\text { Rank by } \\
\text { number }\end{array}$ & $\begin{array}{c}\text { to of } \\
\text { tolal }\end{array}$ \\
\hline 10 - Metal mining & 1 & 15 & 1 & 13 \\
13 - Oil \& gas extraction & 2 & 9 & 7 & 4 \\
73 - Business services & 3 & 6 & 5 & 7 \\
20 - Food \& kindred products & 4 & 5 & 4 & 7 \\
28 - Chemicals \& allied products & 5 & 5 & 6 & 6 \\
$60-$ Depository institutions & 6 & 5 & 8 & 4 \\
$14-$ Nonmetallic minerals, except fuels & 7 & 4 & 29 & 1 \\
$48-$ Communications & 8 & 4 & 2 & 7 \\
$32-$ Stone, clay, glass \& concrete product & 9 & 3 & 13 & 2 \\
87 - Engineering \& management services & 10 & 3 & 15 & 2 \\
37 - Transportation equipment & 14 & 2 & 10 & 2 \\
63 - Insurance carriers & 18 & 2 & 9 & 3 \\
$49-$ Electric, gas \& sanitary services & 20 & 6 & 3 & 7 \\
\hline Sum & & 71 & & 70 \\
\hline \hline
\end{tabular}

We include the 10 most important sectors in terms of number of M\&As for both Africa and Latin America. Therefore, for each rank classification we have included in the table at least ranks from 1 to 10 .

Finally, we disaggregate the data in the two big groups of industries considered for the econometric model: sectors intensive in natural resources and sectors not intensive in natural resources. ${ }^{22}$ Figure 6 shows that, for the five countries most active in M\&As in Africa and the five most active in Latin America, the division of M\&As in sectors intensive and not intensive in natural resources is close to half. Africa, however has on average more M\&As in sectors intensive in natural resources, whereas Latin America has more M\&As in sectors not intensive in natural resources.

\footnotetext{
${ }^{22}$ Appendix E lists which 2 digit SIC codes were included in each group.
} 
Figure 6 -Percentage of $M \& A$ deals on natural resource intensive sectors for the five countries most active in $M \& A s$ in Africa and Latin America.
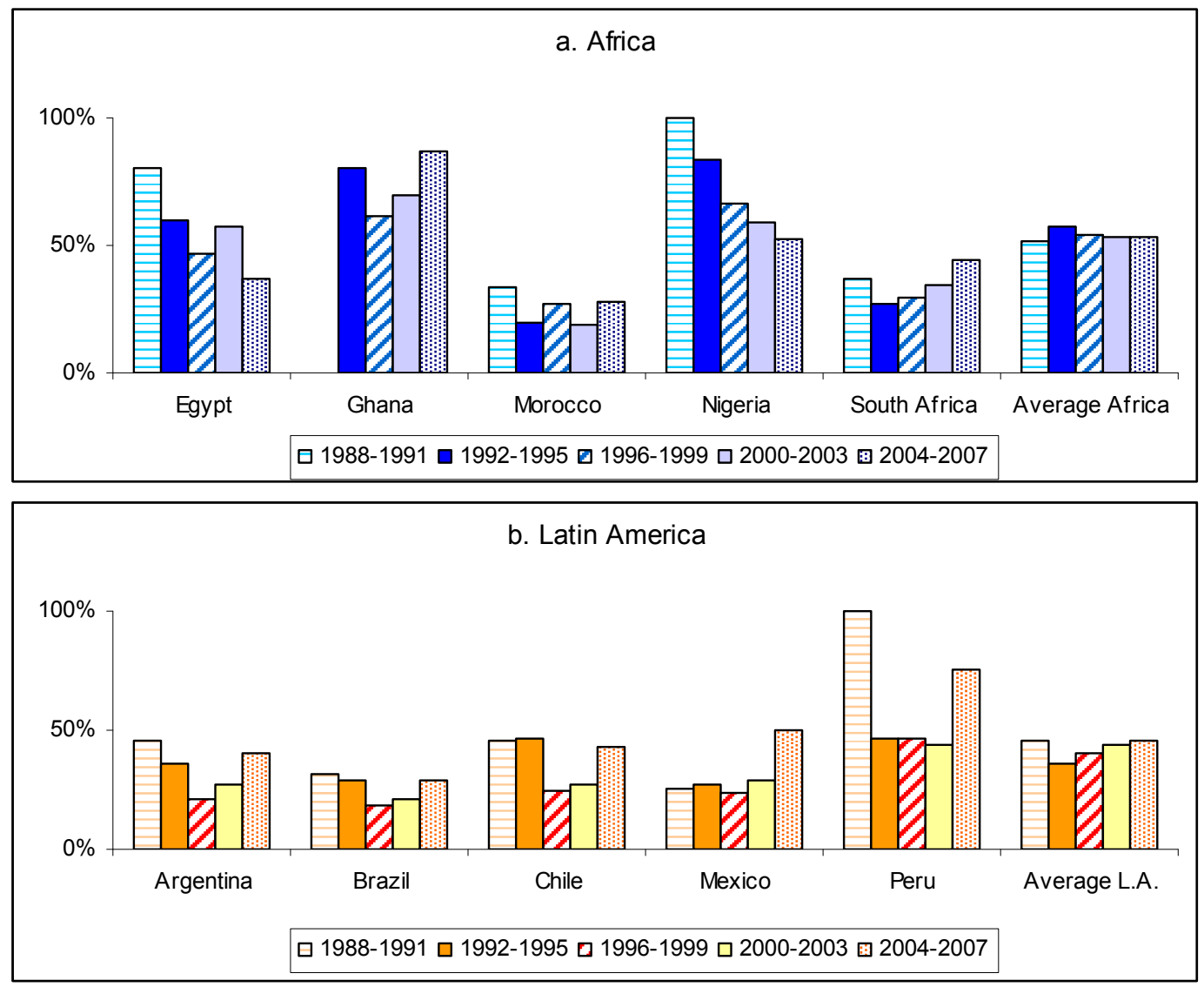

In constructing the averages for Latin America and Africa all of the countries from our dataset were included and not only the specific countries illustrated in the graph.

For this same selection of countries we plot under Figure 7, for four different periods, the number of deals in sectors intensive in natural resources and not intensive in natural resources, alongside with the average of the resource dependency measure. From this small selection of countries we see that there is not a clear pattern among resource dependency and number of deals, as we are not controlling for all the other possible determinants of M\&As. Still, we find that for the countries most active in M\&As, in particular in sectors not intensive in natural resources, (Brazil, Argentina and Mexico), the resource dependency measure is considerably low, always under $10 \%$ of the GDP. This only gives an indication of a negative association between M\&As and resource dependency. In general there is, however, a variety of experiences. The analysis needs to take all other factors that affect the number of M\&As to draw a conclusion in regard this association. 
Figure 7 - Number of $M \& A$ deals on natural resource intensive (or not) sectors for the five countries most active in M\&As in Africa and Latin America, separated in four periods.
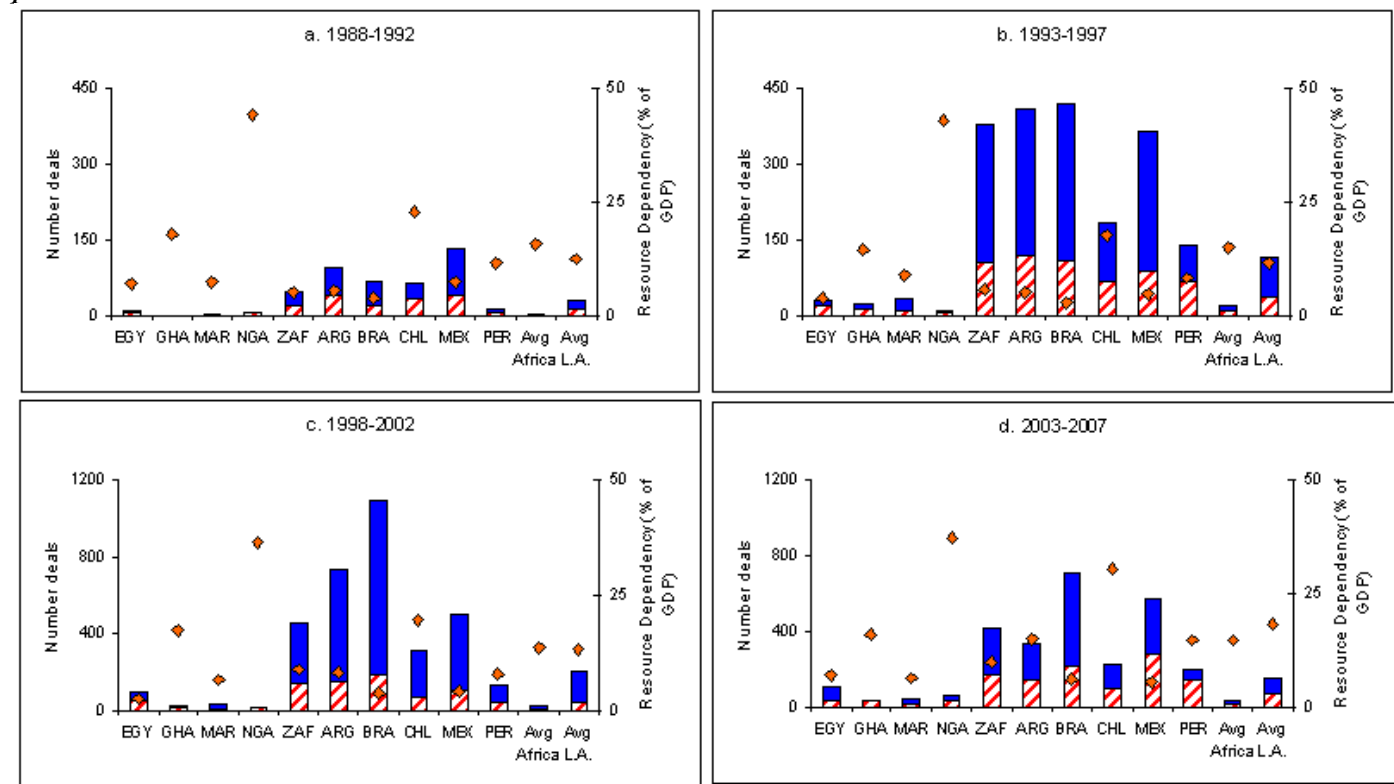

$\square N$ atural Res ources $\square$ Other $\diamond$ Res ource Dependency

Note: $\mathrm{EGY}=$ Egypt GHA $=$ Ghana; $\mathrm{MAR}=$ Morocco $; \mathrm{NGA}=$ Nigeria; $\mathrm{ZAF}=$ South Africa; $\mathrm{ARG}=$ Argentina; $\mathrm{BRA}=$ Brazil; $\mathrm{CHL}=$ Chile; $\mathrm{MEX}=$ Mexico; $\mathrm{PER}=$ Peru; Avg. $=$ Average.

\section{$5 \quad$ Results}

\section{5 a Main results}

As we already anticipated, the model that best fits our data is the ZINB model. We restrict to providing those results, in Tables 4 to 6 . The tables also present the tests results that confirmed that the ZINB was the best model. The Vuong test of non-nested models compares the ZINB with the negative binomial regression model. ${ }^{23}$ The LR test of $\alpha$, the over-dispersion parameter, compares the ZIP and the ZINB models. ${ }^{24}$ For all regressions, the Vuong test supports the ZINB model over the NBRM, while the LR test gives strong evidence to prefer the NBRM over the PRM in the count part of the model.

For our final model we estimated three different regressions. The first one involved the whole dataset without making any distinction in regard to the sectors of the M\&As. The second one restricted to the M\&As in sectors intensive in natural resources, and the

\footnotetext{
${ }^{23}$ The test statistic for the Vuong test has a standard normal distribution with a large positive value favoring the ZINB model and large negative value favoring the negative binomial model.

${ }^{24}$ The null hypothesis of the LR test is $\mathrm{H}_{0}: \alpha=0$.
} 
third on sectors that are not intensive in natural resources. To make this disaggregation we use the classification from appendix E. Tables 4 to 6 presents these results in this order. We called these three different regressions respectively: 'all sectors'; 'natural resources'; and 'other sectors'.

The tables contain the coefficient, standard errors and significance level. For the first part of the model (logit), the coefficient results correspond to the chance of being in the group of zeros M\&As (passive group). Therefore, care must be taken in reading the coefficient signs, since a positive (negative) coefficient means that there is a positive (negative) chance of being in the passive group. For the first part of the model we also report the percent change in odds for one standard deviation in the respective variable. Let the odds of being in the passive group versus on the active group be given by:

$$
\Omega=\frac{\operatorname{Pr}\left(y_{i}^{*}=0 ; z_{i}\right)}{\operatorname{Pr}\left(y_{i}^{*}>0 ; z_{i}\right)}
$$

Suppose $\mathrm{b}$ is the estimated coefficient for some variable, and $\delta$ the standard deviation for non-dummy variables (respectively, a unit change for dummy variables). Then, the odds ratio is given by:

$$
\frac{\Omega\left(z, z_{i}+\delta\right)}{\Omega\left(z, z_{i}\right)}=e^{b \delta}
$$

That is, the odds ratio represents the expected factor change in the odds of being in the passive group for a $\delta$-size change in the variable in question, holding all other variables constant. $^{25}$ Finally, the odds ratio of a positive and a negative magnitude should be compared by inverting one of them. The reason is that a percent change of $100\left(\mathrm{e}^{\mathrm{b} \delta}-1\right)$ has the same magnitude as a negative percent change of $100\left(1 / \mathrm{e}^{\mathrm{b} \delta}-1\right)$ (that is, a 50 percent decline is comparable in magnitude to a 100 percent increase).

\footnotetext{
${ }^{25}$ In tables 4-6 we report $100\left(\mathrm{e}^{\mathrm{b} \delta}-1\right)$, that is, the percent change in odds for a one standard deviation increase in the variable in question.
} 
For the second part of the model (NBRM), we report $100\left(\mathrm{e}^{\mathrm{b} \delta}-1\right)$ which, similarly, denotes the percentage change in expected count for one standard deviation increase in the respective variable, holding all other variables constant. In addition, for the NBRM part of the model the estimated coefficients of the variables measured in natural logarithms can be interpreted as elasticities.

Table 4 shows the results for the case where we consider all sectors together, controlling, among other things, for natural resource dependency. In this case, most of the explanatory variables were statistically significant for both the logit and the negative binomial estimation procedure.

Looking at the results of the logit regression for the aggregated data, some interesting facts stand out. First, the size of the target country (as measured by the log of GDP) does not play a role in determining the prediction of country group, it is only important for those countries in the active group. However, the size of the acquirer country does help determining group membership (every unit standard deviation increase in the log of GDP of the acquirer country decreases the expected probability of being in the passive group by 96.7\%). In fact, this is the most important determinant of group membership, considering the order of economic impact of the results. Following this order, other factors that matter in the prediction of group membership are: GDP per capita of the acquirer country, distance between target and acquirer, degree of trade openness of the acquirer country, GDP per capita of the target country and trade openness of the target country. Comparing the two dummy variables presented in Table 4, having a past colonial relation is a more important determinant of group membership than having a common language, although both are significant. Figure 8 summarizes these results. ${ }^{26}$

\footnotetext{
${ }^{26}$ In figure 8 we include all significant variables, although the dummy variables should only be ranked between one another.
} 
Figure 8 - Significant determinants of $M \& A s$, all sectors
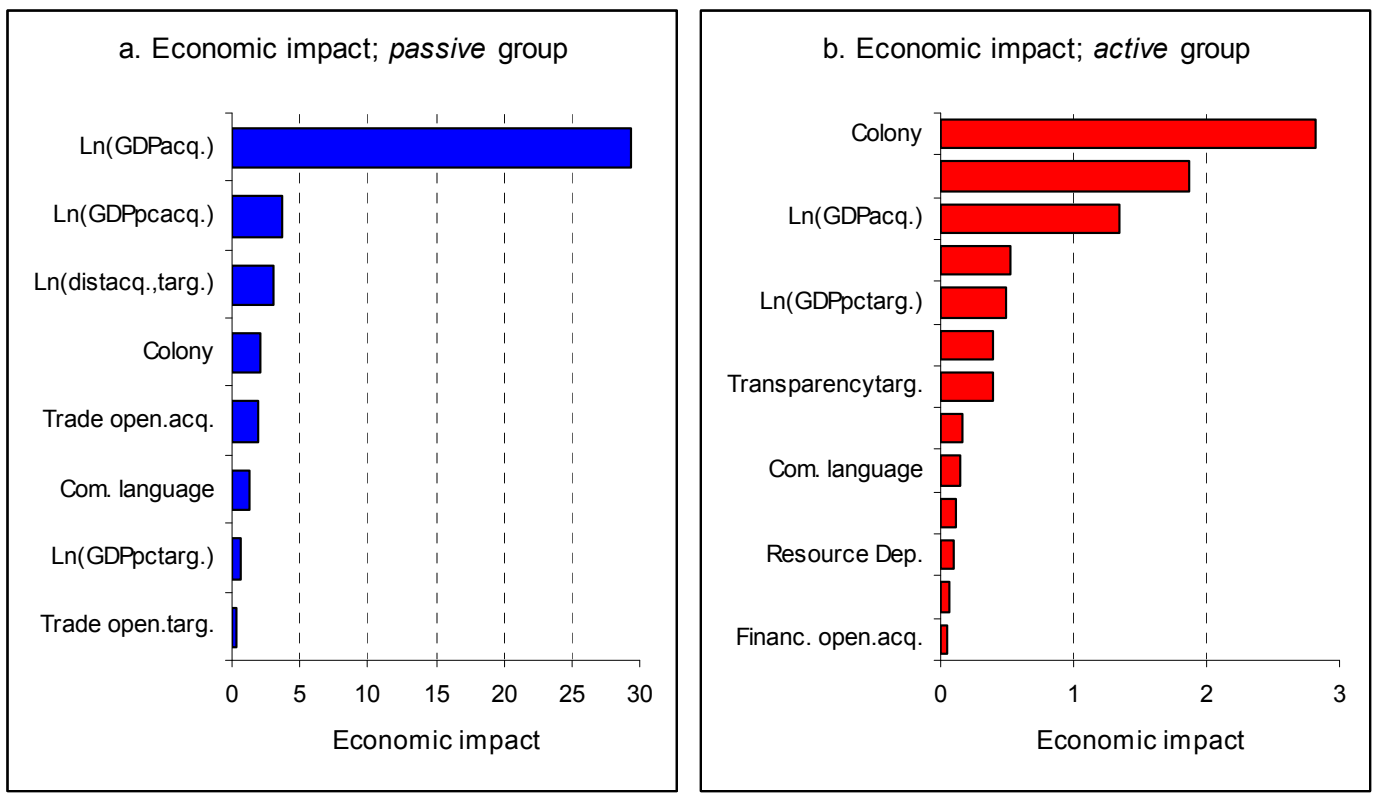

Specifically, the GDP per capita of the target, the distance between the countries, and the measure of trade openness of the target country all increase the chances of being in the passive group of M\&As. The fact that GDP per capita of the target contributes positively to the chance of being in the passive group can be understood by considering this variable as a proxy for wage. This is an approximation done in other empirical works (see di Giovani, 2005; Fingleton, 2008 and Redding and Venables, 2004 for recent examples). In our case it can be taken as a source of comparative advantage which acts as an initial attractor of M\&As. The GDP per capita of the acquirer, on the other hand, contributes negatively to the chance of being in the passive group, as does trade openness of the acquirer country, having a common language and being in a past colonial relation. 
Table 4 - ZINB model for aggregated data

\begin{tabular}{|c|c|c|c|c|c|c|}
\hline \multirow[t]{2}{*}{ "all sectors" } & \multicolumn{3}{|c|}{$\begin{array}{c}\text { Negative Binomial } \\
\text { (Active group) }\end{array}$} & \multicolumn{3}{|c|}{$\begin{array}{c}\text { Logit } \\
\text { (Passive group) }\end{array}$} \\
\hline & \multicolumn{2}{|c|}{ coefficient } & $\begin{array}{l}\% \text { change } \\
\text { expected count }\end{array}$ & \multicolumn{2}{|c|}{ coefficient } & $\begin{array}{l}\% \text { change } \\
\text { odds ratio }\end{array}$ \\
\hline $\operatorname{Ln}\left(\mathrm{GDP}_{\text {targ. }}\right)$ & $\begin{array}{r}0.662 \\
(0.037)\end{array}$ & $* * *$ & 186.6 & $\begin{array}{r}0.136 \\
(0.119)\end{array}$ & & 24.2 \\
\hline $\operatorname{Ln}\left(G P_{\text {acq. }}\right)$ & $\begin{array}{r}0.369 \\
(0.034)\end{array}$ & $* * *$ & 135.0 & $\begin{array}{r}-1.469 \\
(0.101)\end{array}$ & $* * *$ & -96.7 \\
\hline $\operatorname{Ln}\left(G_{D P p} c_{\text {targ. }}\right)$ & $\begin{array}{r}0.358 \\
(0.066)\end{array}$ & $* * *$ & 48.7 & $\begin{array}{r}0.483 \\
(0.218)\end{array}$ & ** & 71.0 \\
\hline $\operatorname{Ln}\left(G_{D P p c} c_{\text {acq. }}\right)$ & $\begin{array}{r}-0.065 \\
(0.103)\end{array}$ & & -9.7 & $\begin{array}{r}-0.991 \\
(0.212)\end{array}$ & $* * *$ & -78.8 \\
\hline $\operatorname{Ln}\left(\right.$ dist $\left._{\text {acq.,targ. }}\right)$ & $\begin{array}{r}-0.655 \\
(0.056) \\
\end{array}$ & $* * *$ & -39.0 & $\begin{array}{r}1.835 \\
(0.153) \\
\end{array}$ & $* * *$ & 299.1 \\
\hline Resource Dep. & $\begin{array}{r}-0.011 \\
(0.005)\end{array}$ & $* *$ & -10.1 & $\begin{array}{r}0.022 \\
(0.017)\end{array}$ & & 24.3 \\
\hline Transparency targ. & $\begin{array}{r}0.247 \\
(0.022)\end{array}$ & $* * *$ & 38.6 & $\begin{array}{r}-0.083 \\
(0.066)\end{array}$ & & -10.4 \\
\hline Trade open.targ. & $\begin{array}{r}-0.008 \\
(0.002)\end{array}$ & $* * *$ & -16.0 & $\begin{array}{r}0.015 \\
(0.005)\end{array}$ & $* * *$ & 40.0 \\
\hline Financ. open.targ. & $\begin{array}{r}0.009 \\
(0.005)\end{array}$ & * & 6.3 & $\begin{array}{r}-0.016 \\
(0.016)\end{array}$ & & -10.0 \\
\hline Trade open.acq. & $\begin{array}{r}-0.003 \\
(0.001)\end{array}$ & ** & -12.0 & $\begin{array}{r}-0.022 \\
(0.004)\end{array}$ & $* * *$ & -64.9 \\
\hline Financ. open.acq. & $\begin{array}{r}0.000 \\
(0.000)\end{array}$ & & 5.0 & $\begin{array}{r}0.001 \\
(0.001)\end{array}$ & & 9.2 \\
\hline Wave(global) & $\begin{array}{r}0.001 \\
(0.000)\end{array}$ & $* * *$ & 52.0 & $\begin{array}{r}-0.000 \\
(0.000)\end{array}$ & & -2.6 \\
\hline Com. language & $\begin{array}{r}0.133 \\
(0.099)\end{array}$ & & 14.3 & $\begin{array}{r}-0.811 \\
(0.245)\end{array}$ & $* * *$ & -55.6 \\
\hline Colony & $\begin{array}{r}1.340 \\
(0.111) \\
\end{array}$ & $* * *$ & 282.0 & $\begin{array}{r}-1.117 \\
(0.420) \\
\end{array}$ & $* * *$ & -67.3 \\
\hline \multicolumn{4}{|c|}{ \# of observations: 79,638} & \multicolumn{3}{|c|}{ \# of nonzero observations: 2,340} \\
\hline \multicolumn{4}{|c|}{$\begin{array}{l}\text { Vuong test of zinb versus negative binomial: } \\
\text { LR test of zip versus zinb }\end{array}$} & $\begin{array}{l}\mathrm{z}=12.40 \\
\chi \operatorname{bar}^{2}=2211\end{array}$ & & $\begin{array}{l}\operatorname{Pr}>z=0.0000 \\
\operatorname{Pr}>\chi b^{2}=0.00\end{array}$ \\
\hline \multicolumn{7}{|c|}{ 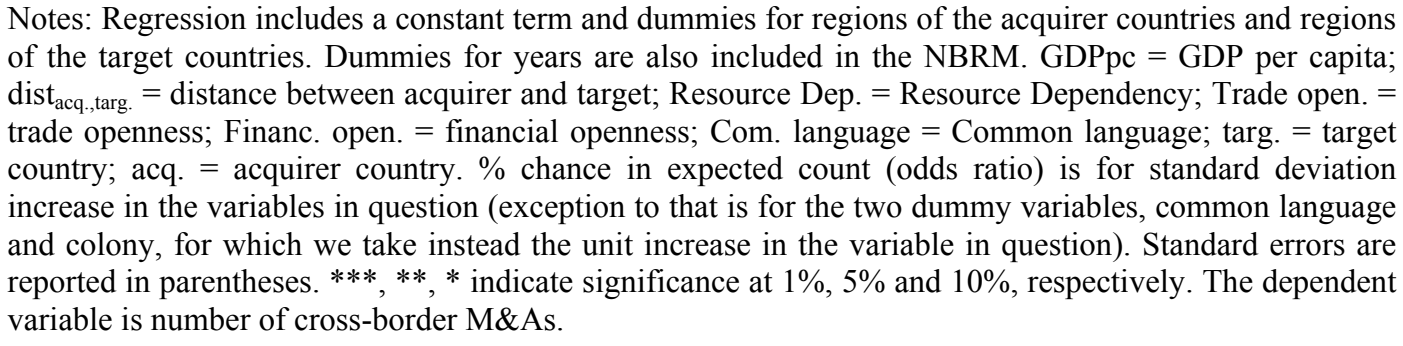 } \\
\hline
\end{tabular}


The interpretation of the results for the negative binomial part is more straightforward and all significant coefficients have the expected sign. The coefficient that we are most interested in is the one of resource dependency. ${ }^{27}$ Holding everything else constant we found that being dependent in natural resources decreases the expected number of M\&As towards developing countries by $10.1 \%{ }^{28}$ Thus, if we would compare our result with the ones found in the literature, ours would be contrary to the empirical findings of e.g. Onyeiwu and Shrestha (2004) and Jensen (2003). Our results are in line with the findings of Gylfason (2004) and with the theoretical literature that associates resource dependency with volatility and consequently lower level of FDI. Moreover, this negative relation between resource dependency and M\&As supports our second hypothesis.

Tables 5 and 6 show that the second hypothesis is also supported by disaggregated data. Table 5 presents the results for the M\&As in sectors intensive in natural resources. In this case we control for both natural resource dependency and natural wealth. We find that for countries in the passive group, a one standard deviation on the natural wealth variable decreases their chance of being in the passive group of M\&As in sectors intensive in natural resources by $51.8 \%$. Nonetheless, natural wealth does not affect the number of M\&As for countries in the active group. This result provides support for our first hypothesis.

Thus, natural wealth is a determinant of being in the passive or active group of M\&As. On the other hand, resource dependency is statistically significant for countries in the active group. Our finding shows that, for sectors intensive in natural resources, a one standard deviation of the resource dependency variable decreases the expected number of M\&As by $15.8 \%$. This finding is in accordance to the one found in Table 4, giving further support to the second hypothesis.

\footnotetext{
${ }^{27}$ In fact, for the whole dataset we could also control for natural wealth, since we have M\&As in sectors intensive in natural resources. We ran similar regression to the one in Table 4 controlling for resource dependency and natural wealth; and another controlling for natural wealth alone. Since in both these cases the variable natural wealth was statistically insignificant, we restricted to reporting the results where we control for resource dependency alone. The other two alternative tables are available upon request.

${ }^{28}$ (for each unit increase in the standard deviation of the resource dependency variable).
} 
A noteworthy point is that when making this disaggregation the impact of the explanatory variables is different than for the aggregated data, and also some coefficients change signs or significance. For example, for the passive group, the GDP per capita of the target country is no longer a significant determinant. This makes sense using the interpretation of the GDP per capita as a proxy for wage. Labour is not the intensive input of production in natural resources intensive sectors. Therefore, the finding that another input, natural wealth, has a statistically significant result for the binary model makes perfect sense.

Another finding is that the GDP of the acquirer has a negative coefficient in the negative binomial model for sectors intensive in natural resources. This can be explained by the fact that many developing countries have a comparative advantage in goods intensive in natural resources, and have a relative lower GDP than the developed economies. Therefore, if developing countries are in the position of acquirers, they tend to be active in sectors intensive in natural resources. More generally, comparing all the coefficient results in Table 4 and 5 shows that the control variables have a different impact depending on the sector to which the M\&A is directed. Therefore the disaggregation can provide important information in establishing the determinants of M\&As.

Finally, the estimation results for the M\&As in sectors that are not intensive in natural resources are much in line with the results for the aggregated data, but the impact of each individual explanatory variable are in general stronger (compare Table 4 with Table 6). For example, for the negative binomial estimation, the GDP of the target increases the expected number of M\&As by $215.4 \%$, as opposed to $186.6 \%$ for the aggregated data.

Also, here we find again evidence for our second hypothesis. Resource dependency is a significant factor in explaining the expected count for countries in the active group of M\&As. The result shows that holding everything else constant, being a resource dependent country decreases the expected number of M\&As in sectors not intensive in natural resources by $17.9 \%$. 
Table 5 - ZINB model for M\&As in sectors intensive in natural resources

\begin{tabular}{|c|c|c|c|c|c|c|}
\hline \multirow{3}{*}{$\begin{array}{l}\text { "Natural } \\
\text { Resources" } \\
\left.\text { Ln(GDP }{ }_{\text {targ. }}\right)\end{array}$} & \multicolumn{3}{|c|}{$\begin{array}{l}\text { Negative Binomial } \\
\text { (Active group) }\end{array}$} & \multicolumn{3}{|c|}{$\begin{array}{c}\text { Logit } \\
\text { (Passive group) }\end{array}$} \\
\hline & \multicolumn{2}{|c|}{ coefficient } & $\begin{array}{c}\% \text { change } \\
\text { expected count }\end{array}$ & \multicolumn{2}{|c|}{ Coefficient } & \multirow{2}{*}{$\begin{array}{l}\% \text { change } \\
\text { odds ratio } \\
67.6\end{array}$} \\
\hline & $\begin{array}{r}0.385 \\
(0.130)\end{array}$ & $* * *$ & 84.6 & $\begin{array}{r}0.324 \\
(0.381)\end{array}$ & & \\
\hline $\operatorname{Ln}\left(\mathrm{GDP}_{\mathrm{acq}}\right)$ & $\begin{array}{r}-0.279 \\
(0.060)\end{array}$ & $* * *$ & -47.1 & $\begin{array}{r}-2.454 \\
(0.195)\end{array}$ & $* * *$ & -99.6 \\
\hline $\operatorname{Ln}\left(\mathrm{GDPpc}_{\text {targ. }}\right)$ & $\begin{array}{r}0.505 \\
(0.142)\end{array}$ & $* * *$ & 77.2 & $\begin{array}{r}0.332 \\
(0.424)\end{array}$ & & 45.7 \\
\hline $\operatorname{Ln}\left(G P p c_{a c q}\right)$ & $\begin{array}{r}0.328 \\
(0.141)\end{array}$ & $* *$ & 66.9 & $\begin{array}{r}-0.447 \\
(0.246)\end{array}$ & * & -50.2 \\
\hline $\operatorname{Ln}\left(\right.$ dist $\left._{\text {acq.,targ. }}\right)$ & $\begin{array}{r}-0.384 \\
(0.084)\end{array}$ & $* * *$ & -25.2 & $\begin{array}{r}2.278 \\
(0.201)\end{array}$ & $* * *$ & 459.0 \\
\hline Resource Dep. & $\begin{array}{r}-0.018 \\
(0.008)\end{array}$ & $* *$ & -15.8 & $\begin{array}{r}-0.002 \\
(0.023)\end{array}$ & & -1.6 \\
\hline $\begin{array}{l}\text { Ln(Natural } \\
\text { wealth) }\end{array}$ & $\begin{array}{r}0.091 \\
(0.099)\end{array}$ & & 12.2 & $\begin{array}{r}-0.575 \\
(0.298)\end{array}$ & $* *$ & -51.8 \\
\hline Transparency & $\begin{array}{r}0.147 \\
(0.035)\end{array}$ & $* * *$ & 20.5 & $\begin{array}{r}-0.326 \\
(0.115)\end{array}$ & $* * *$ & -33.8 \\
\hline Trade open.targ. & $\begin{array}{r}-0.004 \\
(0.003)\end{array}$ & & -7.6 & $\begin{array}{r}0.025 \\
(0.008)\end{array}$ & $* * *$ & 76.9 \\
\hline Financ. open.targ. & $\begin{array}{r}0.009 \\
(0.008)\end{array}$ & & 5.5 & $\begin{array}{r}-0.010 \\
(0.023)\end{array}$ & & -5.9 \\
\hline Trade open.acq. & $\begin{array}{r}-0.016 \\
(0.002)\end{array}$ & $* * *$ & -53.8 & $\begin{array}{r}-0.045 \\
(0.006)\end{array}$ & $* * *$ & -88.6 \\
\hline Financ. open.acq. & $\begin{array}{r}0.001 \\
(0.000)\end{array}$ & $* * *$ & 14.3 & $\begin{array}{r}0.001 \\
(0.001)\end{array}$ & ** & 22.6 \\
\hline Wave(global) & $\begin{array}{r}-0.000 \\
(0.000)\end{array}$ & & -3.7 & $\begin{array}{r}-0.002 \\
(0.001)\end{array}$ & $* * *$ & -39.1 \\
\hline Com. language & $\begin{array}{r}-0.291 \\
(0.140)\end{array}$ & $* *$ & -25.2 & $\begin{array}{l}-0.560 \\
(0.330)\end{array}$ & $*$ & -42.9 \\
\hline Colony & $\begin{array}{r}1.316 \\
(0.182) \\
\end{array}$ & $* * *$ & 273.0 & $\begin{array}{r}-1.044 \\
(0.724)\end{array}$ & & -64.8 \\
\hline \multirow{2}{*}{\multicolumn{4}{|c|}{$\begin{array}{l}\# \text { of observations: } 34,171 \\
\alpha=0.701 \\
\text { Vuong test of zinb versus negative binomial: } \\
\text { LR test of zip versus zinb }\end{array}$}} & \multicolumn{3}{|c|}{$\#$ of nonzero observations: 863} \\
\hline & & & & $\begin{array}{l}\mathrm{z}=12.04 \\
\chi \operatorname{bar}^{2}=253 .\end{array}$ & & $\begin{array}{l}\operatorname{Pr}>z=0.0000 \\
\operatorname{Pr}>\chi b^{2}=0.00\end{array}$ \\
\hline \multicolumn{7}{|c|}{$\begin{array}{l}\text { Notes: Regression includes a constant term and dummies for regions of the acquirer countries and regions } \\
\text { of the target countries. Dummies for years are also included in the NBRM. GDPpc = GDP per capita; } \\
\text { dist } t_{\text {acq.,targ. }}=\text { distance between acquirer and target; Trade open. = trade openness; Financ. open. = financial } \\
\text { openness; Com. language = Common language; targ. = target country; acq. = acquirer country. } \% \text { chance } \\
\text { in expected count (odds ratio) is for standard deviation increase in the variables in question (exception to } \\
\text { that is for the two dummy variables, common language and colony, for which we take instead the unit } \\
\text { increase in the variable in question). Standard errors are reported in parentheses. } * * *, * *, * \text { indicate } \\
\text { significance at } 1 \%, 5 \% \text { and } 10 \% \text {, respectively. The dependent variable is number of cross-border M\&As. }\end{array}$} \\
\hline
\end{tabular}


Table 6 - ZINB model for M\&As in sectors not intensive in natural resources

\begin{tabular}{|c|c|c|c|c|c|c|}
\hline \multirow[t]{2}{*}{ "other sectors" } & \multicolumn{3}{|c|}{$\begin{array}{c}\text { Negative Binomial } \\
\text { (Active group) }\end{array}$} & \multicolumn{3}{|c|}{$\begin{array}{c}\text { Logit } \\
\text { (Passive group) }\end{array}$} \\
\hline & \multicolumn{2}{|c|}{ coefficient } & $\begin{array}{l}\% \text { change } \\
\text { expected count }\end{array}$ & \multicolumn{2}{|c|}{ coefficient } & $\begin{array}{l}\text { \% change } \\
\text { odds ratio }\end{array}$ \\
\hline $\mathrm{Ln}\left(\mathrm{GDP}_{\text {targ. }}\right)$ & $\begin{array}{r}0.723 \\
(0.041)\end{array}$ & & 215.4 & $\begin{array}{r}0.211 \\
(0.189)\end{array}$ & & 39.8 \\
\hline $\operatorname{Ln}\left(G P_{\text {acq. }}\right)$ & $\begin{array}{r}0.707 \\
(0.037)\end{array}$ & $* * *$ & 414.7 & $\begin{array}{l}-1.201 \\
(0.133)\end{array}$ & $* * *$ & -93.8 \\
\hline $\operatorname{Ln}\left(\mathrm{GDPpc}_{\mathrm{targ}}\right)$ & $\begin{array}{r}0.396 \\
(0.073)\end{array}$ & $* * *$ & 55.2 & $\begin{array}{r}0.876 \\
(0.313)\end{array}$ & $* * *$ & 164.1 \\
\hline $\operatorname{Ln}\left(\mathrm{GDPpc}_{\mathrm{acq}}\right)$ & $\begin{array}{l}-0.067 \\
(0.110)\end{array}$ & & -10.0 & $\begin{array}{r}-1.009 \\
(0.260)\end{array}$ & $* * *$ & -79.3 \\
\hline $\operatorname{Ln}\left(\right.$ dist $\left._{\text {acq.,targ. }}\right)$ & $\begin{array}{r}-0.993 \\
(0.065)\end{array}$ & *** & -52.7 & $\begin{array}{r}1.239 \\
(0.208)\end{array}$ & $* * *$ & 154.6 \\
\hline Resource Dep. & $\begin{array}{l}-0.020 \\
(0.006)\end{array}$ & $* * *$ & -17.9 & $\begin{array}{r}-0.009 \\
(0.032)\end{array}$ & & -8.5 \\
\hline Transparency & $\begin{array}{r}0.301 \\
(0.024)\end{array}$ & $* * *$ & 48.8 & $\begin{array}{r}0.124 \\
(0.095)\end{array}$ & & 17.8 \\
\hline Trade open.targ. & $\begin{array}{l}-0.014 \\
(0.002)\end{array}$ & $* * *$ & -26.2 & $\begin{array}{r}0.015 \\
(0.008)\end{array}$ & ** & 40.0 \\
\hline Financ. open.targ. & $\begin{array}{r}0.018 \\
(0.006)\end{array}$ & $* * *$ & 12.1 & $\begin{array}{r}-0.000 \\
(0.027)\end{array}$ & & -0.3 \\
\hline Trade open.acq. & $\begin{array}{r}0.002 \\
(0.001)\end{array}$ & * & 8.5 & $\begin{array}{r}-0.020 \\
(0.005)\end{array}$ & $* * *$ & -62.1 \\
\hline Financ. open.acq. & $\begin{array}{r}0.000 \\
(0.000)\end{array}$ & & 6.9 & $\begin{array}{r}0.001 \\
(0.001)\end{array}$ & & 19.3 \\
\hline Wave(global) & $\begin{array}{r}0.001 \\
(0.000)\end{array}$ & $* * *$ & 52.8 & $\begin{array}{r}-0.000 \\
(0.000)\end{array}$ & & -6.5 \\
\hline Com. language & $\begin{array}{r}0.581 \\
(0.113)\end{array}$ & $* *$ & 78.8 & $\begin{array}{r}-0.631 \\
(0.374)\end{array}$ & * & -46.8 \\
\hline Colony & $\begin{array}{r}1.171 \\
(0.123) \\
\end{array}$ & $* * *$ & 222.5 & $\begin{array}{r}-1.768 \\
(0.620) \\
\end{array}$ & $* * *$ & -82.9 \\
\hline \multirow{2}{*}{\multicolumn{4}{|c|}{$\begin{array}{l}\text { \# of observations: } 39,819 \\
\alpha=0.518 \\
\text { Vuong test of zinb versus negative binomial: } \\
\text { LR test of zip versus zinb }\end{array}$}} & \multicolumn{3}{|c|}{ \# of nonzero observations: 1,387} \\
\hline & & & & $\begin{array}{l}\mathrm{z}=7.79 \\
\chi \operatorname{bar}^{2}=556.67\end{array}$ & & $\begin{array}{l}\operatorname{Pr}>z=0.0000 \\
\operatorname{Pr}>\chi b^{2}=0.00\end{array}$ \\
\hline $\begin{array}{l}\text { Notes: Regression } \\
\text { of the target countr } \\
\text { dist } \\
\text { trade.targ. = distanc } \\
\text { country; acq. } \text {; Fin } \\
\text { in the variables in } \\
\text { colony, for which } \mathrm{w} \\
\text { in parentheses. } * * * \text {, } \\
\text { number of cross-bor }\end{array}$ & $\begin{array}{l}\text { es a consta } \\
\text { ummies } \mathrm{f} \\
\text { veen acqui } \\
\text { open. = fir } \\
\text { ountry. \% } \\
\text { ion (excep } \\
\text { instead th } \\
\text { indicate si } \\
\text { I\&As. }\end{array}$ & $\begin{array}{l}\text { rer } \\
\text { lan } \\
\text { ch } \\
\text { tio }\end{array}$ & $\begin{array}{l}\text { and dummies for } \\
\text { s are also included } \\
\text { target; Resource } D \\
\text { openness; Com. la } \\
\text { in expected count } \\
\text { that is for the two } \\
\text { ncrease in the varia } \\
\text { ace at } 1 \%, 5 \% \text { and }\end{array}$ & $\begin{array}{l}\text { ons of the acqui } \\
\text { the NBRM. GD } \\
=\text { Resource Dep } \\
\text { age = Common } \\
\mathrm{s} \text { ratio) is for sta } \\
\text { immy variables, } \\
\text { in question). Sta }\end{array}$ & an & $\begin{array}{l}\text { ntries and regions } \\
\text { GDP per capita; } \\
\text { cy; Trade open. } \\
\text { ge; targ. = target } \\
\text { deviation increase } \\
\text { on language and } \\
\text { arrors are reported } \\
\text { endent variable is }\end{array}$ \\
\hline
\end{tabular}




\section{5b Robustness check}

- 5b1 Lag natural resources

As a robustness check we run the same models as before but using a one-year lag for the resource dependency variable. We check then whether the coefficient on resource dependency, in particular, remains close (in terms of value and statistical significance) to the one found in our previous results. One concern here is that we might have an endogeneity problem. That is, it is possible that because a certain country receives more (less) M\&As the economy becomes more (less) diversified, leading to a lower (higher) degree of resource dependency.

We use a common method to deal with endogenous variable in a time series framework: lagging the endogenous variable, in our case, by one period. This is the only change in our new estimation of the model. The results we present in appendix E under Tables A.5, A.6 and A.7. A comparison between Tables A.5 and 4; and A.6 and 5; A.7 and 6 shows that the change in coefficient estimates and significance level is very small. This indicates that if there is an endogeneity problem this would lead to a very small bias of our results. Therefore, the analysis with our main results is not affected by an endogeneity problem.

In particular, the conclusion for the impact of resource dependency remains the same: regardless of the sector there is a negative and significant impact of resource dependency on the number of M\&As. This result provides robust evidence for the second hypothesis.

- 5 b2 Natural wealth versus resource dependency

We defend in this paper that a sector disaggregation is important to understand the determinants of M\&As. Moreover, it highlights the choice of the measure of "natural resources'. Both natural wealth and resource dependency are relevant measures. However, whereas the first is only relevant for sectors intensive in natural resources, the second is relevant for all sectors. In sectors intensive in natural resources the measure of natural wealth indicates the comparative advantage in these sectors. Nonetheless, for all sectors a measure of resource dependency is relevant. To measure this dependency, we 
used 'exports of natural resources as a percentage of GDP' as an indication of how dependent the country is on natural resources revenues. The higher this measure, the higher the instability created in the (whole) economy for a given price fluctuation.

If this reasoning is correct, then natural wealth per se should not affect M\&As in sectors not intensive in natural resources. As we have already mentioned, there are many examples of countries rich in natural resources that have a diversified economy, and therefore natural wealth should not impose a problem to attract M\&As in sectors not intensive in natural resources. This is indeed what we find. Table A.8 in the appendix shows the results when we regress the dataset on sectors not intensive in natural resources, controlling for both natural wealth and resource dependency. For sectors not intensive in natural resources the only relevant variable is resource dependency. Natural wealth is, in this case, statistically insignificant.

- 5 b3 Alternative measure for natural resource dependency

As a final robustness check, we use an alternative measure of natural resource dependency: the percentage of natural wealth over total wealth, which is also provided from the unpublished estimates of natural wealth of the World Bank. This measure gives an indication of the importance of natural resources for the economy. Nonetheless, it is a weaker measure of the actual dependency when compared to the exports of natural resources to GDP. The result reinforces our findings for the second hypothesis. Again we find that natural resource dependency has a negative impact in the attraction of M\&As in sectors not intensive in natural resources (a one percent increase in the measure for countries in the active group decreases the expected number of M\&As by 15.3\%). Table A.9 in the appendix presents these results. However, the results were not statistically significant when we considered the aggregated data (results available upon request).

\section{Conclusion}

Using data from Thomson Financial Investment Banking for 49 countries from Africa and Latin America during the period 1988 until 2007, we estimated the effect of 'natural resources' on the number of cross-border M\&As by using a ZINB gravity type of 
model. Furthermore, we disaggregated the data into sectors intensive in natural resources and sectors not intensive in natural resources. We proposed and tested two hypotheses motivated by the resource curse literature and M\&As literature. Overall, we found strong support for both our hypotheses: countries with a high dependency on natural resources attract fewer M\&As in all sectors; and countries with a comparative advantage in natural resources attract more M\&As in sectors intensive in natural resources.

We showed that the appropriate measure for 'natural resources' depends on the target sector of M\&As. In sectors intensive in natural resources, a measure of resource dependency and of natural wealth should be used. In sectors not intensive in natural resources, on the other hand, only a measure of resource dependency is indicated. This shows that part of the confusion in the literature originates from the misleading interchange of the variables natural wealth and resource dependency. We show that, in fact, both measures should be used either simultaneously (for sectors intensive in natural resources) or the resource dependency variable alone (for sectors not intensive in natural resources).

Table 7 - Effect of 'natural resources' on target M\&As in three groups of sectors

\begin{tabular}{lc:cc}
\hline \hline & "All sectors" & "Natural Resources" & "Other sectors" \\
\hline Resource Dependency & - & - & - \\
Natural Wealth & 0 & + & 0 \\
\hline \hline
\end{tabular}

Table 7 summarizes our findings for 'natural resources'. Overall resource dependency has a negative effect on target M\&As. This finding is preserved by disaggregating the data in sectors intensive and not intensive in natural resources. Therefore, there is strong evidence for our second hypothesis. Being dependent on natural resources is detrimental to the attraction of M\&As. Natural wealth has a positive effect on sectors intensive in natural resources. Being wealthy in natural resources is favourable to the attraction of M\&As in sectors intensive in natural resources. Natural wealth is not a statistically significant variable for sectors not intensive in natural resources. Using aggregated data 
the positive effect of natural resource wealth on M\&As disappears. We also confirmed, therefore, our first hypothesis.

Our research showed that there is no evidence suggesting an endogeneity problem. Considering the lag of the resource dependency variable we found no significant change to the estimated coefficients. Therefore, we concluded that our results were robust to a possible endogeneity bias. A suggestion for future research would be to solve the ZINB model for the case that an endogenous variable is present and re-estimate the model. Still, as we pointed out, we do not think this would significantly change the results.

Our hypotheses indicate that resource dependency leads to a concentration of sectors in the target economy that are subject to M\&As. Therefore, a suggestion is to estimate the effect of resource dependency on the number of different sectors that M\&As are directed to. This research would contribute to understand the impact that resource dependency has on M\&As. In particular, we expect it to give further indication that countries with a high dependency on natural resources have a high sector concentration of M\&As.

\section{References}

Anderson, J. E. and van Wincoop, Eric. (2003) "Gravity with gravitas: a solution to the border puzzles.” The American Economic Review, vol. 93, No.1, 170-192.

Asiedu, E. and Lien, D. (2003) "Capital controls and foreign direct investment." World Development, vol. 32, No.3, 479-490.

Baldwin, R. and Taglioni, D. (2006) "Gravity for dummies and dummies for gravity equations." CEPR Discussion Paper Series, No. 5850.

Borensztein, E.; de Gregorio, J. and Lee, J-W. (1998) "How does foreign direct investment affect economic growth?” Journal of International Economics, 45(1), 115-135.

Brakman, S.; Garita, G.; Garretsen, H. and van Marrewijk, C. (2008) "Unlocking the value of cross-border mergers and acquisitions." CESifo Working Papers, No. 2294. 
Brakman, S.; Garretsen, H. and van Marrewijk, C. (2007) "Cross-border mergers \& acquisitions: the facts as a guide for international economics" in: G. Gregoriou and L. Renneboog (eds.), International Mergers and Acquisitions Activity since 1990: Recent Research and Quantitative Analysis, Academic Press / Elsevier, MA, Ch. 2: 23-49.

Brakman, S.; Garretsen, H. and van Marrewijk, C. (2008) "Cross-border mergers and acquisitions: on revealed comparative advantage and merger waves." mimeo.

Brunnschweiler, C. N. "Cursing the blessing? (2008) Natural resource abundance, institutions, and economic growth.” World Development, vol.36, No.3, 399-419.

Deichmann, J. I.; Eshghi, A.; Haughton, D. M.; Sayek, S. and Teebagy, N. C. (2003) "Foreign direct investment in the Eurasian transition states." Eastern European Economics, vol. 41, no.1, 5-34.

de Melo, M.; Denizer, C.; Gelb, A. And Tenev. Stoyan (1997) "Circumstance and choice: the role of initial conditions and policies in transition economies." World Bank Policy Research Working Paper, no. 1866.

di Giovanni, J. (2005) "What drives capital flows? The case of cross-border M\&A activity and financial deepening." Journal of International Economics, 65, 127149.

Evenett, S. J. (2003) "The cross border mergers and acquisitions wave of the late 1990s.” NBER Working Paper Series, No. 9655.

Evenett, S. J. and Keller, W. (2002) "On the theories explaining the success of the gravity equation.” Journal of Political Economy, vol. 110, No.21.

Farrell, J. and Shapiro, C. "Horizontal mergers: an equilibrium analysis." The American Economic Review, vol. 80, No.1, 107-126.

Fingleton, B. (2008) "Competing models of global dynamics: Evidence from panel models with spatially correlated error components." Economic Modelling, 25, 542-558.

Garita, G. and van Marrewijk, C. (2008) "Countries of a feather flock together Mergers and acquisitions in the global economy." Tinbergen Institute Discussion Paper, No.067-2.

Gylfason, T. (2004) "Natural resources and economic growth: from dependence to diversification." CEPR Discussion Paper Series, No.4804. 
Haskel, J. E.; Pereira, S. C. And Slaughter, M. J. (2007) "Does inward foreign direct investment boost the productivity of domestic firms?" The Review of Economics and Statistics, 89(3), 482-496.

Hausmann, R. and Fernández-Arias, E. (2000) "Foreign direct investment: good cholesterol." Inter-American Development Bank Working Paper, No.417.

Head, K. and Mayer, T. (2004) "Market potential and the location of Japanese investment in the European Union." The Review of Economics and Statistics, 86(4), 959-972.

Helpman, E.; Melitz, M. J. and Rubinstein, Y. (2007) "Estimating trade flows: trading partners and trading volumes." NBER Working Paper Series, No.12927.

Helpman, E.; Melitz, M. J. and Yeaple, S. R. (2004) "Export versus FDI with heterogeneous firms.” The American Economic Review, vol. 94, No.1.

Hijzen, A.; Gorg, H.; Manchin, M. (2008) "Cross-border mergers and acquisitions and the role of trade costs." European Economic Review, 52, 849-866.

Hilbe, J. M. (2007) "Negative binomial regression." Cambridge University Press.

Jensen, N. M. (2003) "Democratic governance and multinational corporations: political regimes and inflows of foreign direct investment." International Organization, 57, 587-616.

Markusen, J. R. (1995) "The boundaries of multinational enterprises and the theory of international trade." Journal of Economic Perspectives, vol.9, No.2, 169-189.

Mehlum, H.; Moene, K. and Torvik, R. (2006) "Institutions and the resource curse." The Economic Journal, 116, January, 1-20.

Neary, J. P. (2007) "Cross-border mergers as instruments of comparative advantage." University of Oxford and CEPR, May 30.

Neary, J. P. (2003) "Globalization and market structure." Journal of European Economic Association, pp.245-271.

Neary, J. P. (2006) "Trade costs and foreign direct investment." CEPR Discussion Paper Series, No.5933.

Onyeiwu, S. and Srestha, H. (2004) "Determinants of foreign direct investment in Africa.” Journal of Developing Societies, pp.89-106.

Papyrakis, E. and Gerlagh, R. (2003) “Natural resources: a blessing or a curse?” FEEM Working Paper, No.8. 
Papyrakis, E. and Gerlagh, R. (2004) "The resource curse hypothesis and its transmission channels." Journal of Comparative Economics, 32, 181-193.

Perry, M.K. and Porter, R.H. "Oligopoly and the incentive for horizontal merger." The American Economic Review, vol. 75, No.1, 219-227.

Poelhekke, S. and van der Ploeg, F. (2007) "Volatility, financial development and the natural resource curse." CEPR Discussion Paper Series, No.6513.

Ramos, L. M.; Zarzoso, I. M. and Burguet, C. S. (2007) “The role of distance in gravity equations: is there really a missing globalization puzzle?" The B.E. Journal of Economic Analysis \& Policy, Vol.7, Issue 1.

Redding, S. and Venables, A.J. (2004) "Economic geography and international inequality." Journal of International Economics, 62, 53-82.

Robinson, J.A.; Torvik, R. and Verdier, T. (2006) "Political foundations of the resource curse." Journal of Development Economics, 79, 447-468.

Sachs, D. J.; Warner, M. A. (1995) "Natural resource abundance and economic growth.” NBER Working Paper Series, No.5398.

Sala-i-Martin, X. and Subramanian, A. (2003) "Addressing the natural resource curse: an illustration from Nigeria." IMF Working Paper, 139.

Shatz, J. H. and Venables, J.A. (2000) "The geography of international investment." Policy Research Working Paper, 2338.

Silva, J. M. C. S. and Tenreyro, S. (2006) "The log of gravity." The Review of Economics and Statistics, 88(4): 641-658.

Unctad (2006) "FDI from developing and transition economies: implications for development." World Investment Report.

van der Ploeg, F. (2006) "Challenges and opportunities for resource rich economies." CEPR Discussion Paper Series, No.5688. 


\section{Appendix}

\section{Appendix A - List of countries}

Table A.1. - List of the countries included in the dataset and respective number of population in 2000, according to WDI/ World Bank

\begin{tabular}{|c|c|c|c|c|c|}
\hline \multicolumn{6}{|c|}{ Population size (millions, 2000) } \\
\hline \multicolumn{4}{|c|}{ African Countries } & \multicolumn{2}{|c|}{ Latin American Countries } \\
\hline Nigeria & 124.8 & Zimbabwe & 12.6 & Brazil & 173.9 \\
\hline Egypt & 67.3 & Niger & 11.8 & Mexico & 98.0 \\
\hline Ethiopia & 64.3 & Mali & 11.6 & Colombia & 41.7 \\
\hline Congo, Dem. Rep. & 50.1 & Malawi & 11.5 & Argentina & 36.9 \\
\hline South Africa & 44.0 & Burkina Faso & 11.3 & Peru & 26.0 \\
\hline Tanzania & 33.8 & Zambia & 10.7 & Venezuela & 24.3 \\
\hline Sudan & 32.9 & Senegal & 10.3 & Chile & 15.4 \\
\hline Kenya & 30.7 & Tunisia & 9.6 & Ecuador & 12.3 \\
\hline Algeria & 30.5 & Chad & 8.2 & Guatemala & 11.2 \\
\hline Morocco & 28.5 & Guinea & 8.2 & Cuba & 11.1 \\
\hline Uganda & 24.3 & Rwanda & 8.0 & Dominican Republic & 8.7 \\
\hline Ghana & 19.9 & Benin & 7.2 & Bolivia & 8.3 \\
\hline Mozambique & 17.9 & Somalia & 7.0 & Haiti & 7.9 \\
\hline Cote d'Ivoire & 16.7 & Burundi & 6.5 & & \\
\hline Madagascar & 16.2 & Togo & 5.4 & & \\
\hline Cameroon & 14.9 & Libya & 5.3 & & \\
\hline Angola & 13.8 & & & & \\
\hline Total, Africa: & 775.7 & & & Total, Latin America: & 493.7 \\
\hline
\end{tabular}

\section{Appendix B - List of regions}

Table A.2. - List of the regions used in the estimation model, based on the World Bank's grouping in global regions.

\begin{tabular}{|c|c|c|c|}
\hline \multicolumn{2}{|r|}{ Target countries regions } & \multicolumn{2}{|r|}{ Acquirer countries regions } \\
\hline LAC & $\begin{array}{l}\text { Latin American and the } \\
\text { Caribbean }\end{array}$ & AAS & Australasia \\
\hline MENA & Middle East and North Africa & EAP & East Asia and Pacific \\
\hline SSA & Sub-Sahara Africa & ECA & East Europe and Central Asia \\
\hline & & & $\begin{array}{l}\text { Latin American and the } \\
\text { Caribbean }\end{array}$ \\
\hline & & MENA & Middle East and North Africa \\
\hline & & NAM & North America \\
\hline & & SA & South Asia \\
\hline & & SSA & Sub-Sahara Africa \\
\hline & & WEUR & Western Europe \\
\hline
\end{tabular}




\section{Appendix C - Data sources}

Table A.3-Details for variables in the regression model.

\begin{tabular}{|c|c|c|c|}
\hline Variable & Definition & Source & Period \\
\hline M\&A flows & Number of deals & $\begin{array}{l}\text { Thomson } \\
\text { Financial } \\
\text { Investment } \\
\text { Banking }\end{array}$ & $1988-2007$ \\
\hline $\begin{array}{l}\text { GDP, GDP per } \\
\text { capita }\end{array}$ & Constant 2000 US\$ & World Bank, WDI & $1988-2007$ \\
\hline Distance & $\begin{array}{l}\text { Simple distance (most populated } \\
\text { cities, } \mathrm{km} \text { ) }\end{array}$ & CEPII & \\
\hline Common language & $\begin{array}{l}1 \text { for common official or primary } \\
\text { language }\end{array}$ & CEPII & \\
\hline Colony & $\begin{array}{l}1 \text { for pairs ever in colonial } \\
\text { relationship }\end{array}$ & CEPII & \\
\hline $\begin{array}{l}\text { Resource } \\
\text { dependency }\end{array}$ & $\begin{array}{l}\text { Primary commodities exports ( } \% \\
\text { of GDP). Computed using the } \\
\text { following variables: Agricultural } \\
\text { raw materials exports ( } \% \text { of } \\
\text { merchandise exports); Food } \\
\text { exports ( } \% \text { of merchandise } \\
\text { exports); Fuel exports ( } \% \text { of } \\
\text { merchandise exports); Ores and } \\
\text { metal exports ( } \% \text { of merchandise } \\
\text { exports); Merchandise exports } \\
\text { (current US\$); and GDP (current } \\
\text { US\$) }\end{array}$ & World Bank, WDI & $1988-2007$ \\
\hline Natural capital & $\begin{array}{l}\text { Constant } 2005 \text { US\$. Comprises: } \\
\text { crop, pasture land, forest(timber), } \\
\text { forest(non-timber), protected } \\
\text { areas, oil, natural gas, hard coal, } \\
\text { soft coal and minerals }\end{array}$ & $\begin{array}{l}\text { Unpublished } \\
\text { World Bank } \\
\text { estimates }\end{array}$ & $\begin{array}{l}1995,2000 \\
\text { and } 2005\end{array}$ \\
\hline Corruption & Index of the perception of the & Transparency & 1988-1992; \\
\hline $\begin{array}{l}\text { Perception Index } \\
\text { (CPI) }\end{array}$ & $\begin{array}{l}\text { degree of corruption as seen by } \\
\text { business people and country } \\
\text { analyst. Ranges from } 10 \text { (highly } \\
\text { clean) and } 0 \text { (highly corrupt) }\end{array}$ & International & $1995-2007$ \\
\hline Trade openness & Trade $(\%$ of GDP) & World Bank, WDI & $1988-2007$ \\
\hline Financial openness & $\begin{array}{l}\text { Gross private capital flows (\% of } \\
\text { GDP) }\end{array}$ & World Bank, WDI & $1988-2005$ \\
\hline
\end{tabular}




\section{Appendix D - 2 digit SIC Code}

Table A.4 - Two digit SIC code description

\begin{tabular}{|c|c|c|c|}
\hline Code & SIC description & Code & SIC description \\
\hline 01 & Agricultural production - crops & 49 & Electric, gas \& sanitary services \\
\hline 02 & Agricultural production - livestock & 50 & Wholesale trade-durable goods \\
\hline 07 & Agricultural services & 51 & Wholesale trade-nondurable goods \\
\hline 08 & Forestry & 52 & $\begin{array}{l}\text { Building materials, hardware, garden } \\
\text { supply \& mobile }\end{array}$ \\
\hline 09 & Fishing, hunting \& trapping & 53 & General merchandise stores \\
\hline 10 & Metal mining & 54 & Food stores \\
\hline 12 & Coal mining & 55 & Autom. dealers \& gasoline stations \\
\hline 13 & Oil \& gas extraction & 56 & Apparel \& accessory stores \\
\hline 14 & Nonmetallic minerals, except fuels & 57 & Furniture, home furn. \& equip. stores \\
\hline 15 & General building contractors & 58 & Eating \& drinking places \\
\hline 16 & Heavy construction contractors & 59 & Miscellaneous retail \\
\hline 17 & Special trade contractors & 60 & Depository institutions \\
\hline 20 & Food \& kindred products & 61 & Nondepository credit institutions \\
\hline 21 & Tobacco manufactures & 62 & $\begin{array}{l}\text { Security, commodity brokers \& } \\
\text { services }\end{array}$ \\
\hline 22 & Textile mill products & 63 & Insurance carriers \\
\hline 23 & Apparel \& other textile products & 64 & Insurance agents, brokers \& service \\
\hline 24 & Lumber \& wood products & 65 & Real state \\
\hline 25 & Furniture \& fixtures & 67 & Holding \& other investment offices \\
\hline 26 & Paper \& allied products & 70 & Lodging places \\
\hline 27 & Printing \& publishing & 72 & Personal services \\
\hline 28 & Chemicals \& allied products & 73 & Business services \\
\hline 29 & Petroleum \& coal products & 75 & Autom. repair, services \& parking \\
\hline 30 & Rubber \& plastics products & 76 & Miscellaneous repair services \\
\hline 31 & Leather \& leather products & 78 & Motion pictures \\
\hline 32 & Stone, clay, glass \& concrete product & 79 & Amusement \& recreational services \\
\hline 33 & Primary metal industries & 80 & Health services \\
\hline 34 & Fabricated metal products & 81 & Legal services \\
\hline
\end{tabular}


35 Industrial machinery \& equipment

36 Electrical \& electronic equipment

37 Transportation equipment

$38 \quad$ Instruments \& related products

39 Misc. manufacturing industries

41 Local \& interurban passenger transit

42 Trucking \& warehousing

43 Postal Service

$44 \quad$ Water transportation

45 Transportation by air

46 Pipelines, except natural gas

47 Transportation services

48 Communications
82 Educational services

83 Social services

84 Museums, art galleries, botanical \& zoological garden

86 Membership organizations

87 Engineering \& management services

88 Private households

89 Miscellaneous services

91 Public, legislative, \& general govern.

92 Justice, public order \& safety

93 Finance, taxation \& monetary policy

94 Administration of human resources

95 Environmental quality \& housing

96 Administration: economic programs

$97 \quad$ National security \& internat. affairs 


\section{Appendix E - Selection of Natural Resource and Primary Sectors based on factor intensity}

Our main reference used to disaggregate the data between Natural Resources Intensive Sectors and Not Intensive in Natural Resources Sectors was the classification of sectors by factor intensity from the Empirical Trade Analysis - Center:

http://www2.econ.uu.nl/users/marrewijk/eta/index.htm

2 Digit SIC code which were considered as intensive in natural resource and primary goods ('Natural Resources'):

01 (Agricultural production - crops); 02 (Agricultural production - livestock); 07 (Agricultural services); 08 (Forestry); 09 (Fishing, hunting, and trapping); 10 (Metal mining); 12 (Coal mining); 13 (Oil and gas extraction); 14 (Nonmetallic minerals, except fuel); 20 (Food and kindred products); 21 (Tobacco manufacturers); 24 (Lumber and wood products); 29 (Petroleum and coal products); 31 (Leather and leather products); 32 (Stone, clay, glass, and concrete products); 33 (Primary metal industries).

2 Digit SIC code which were not considered as intensive in natural resource and primary goods (“other”):

15 (General building contractors); 16 (Heavy construction contractors); 17 (Special trade contractors); 22 (Textile mill products); 23 (Apparel and other textile products); 25 (Furniture and fixtures); 26 (Paper and allied products); 27 (Printing and publishing); 28 (Chemicals and allied products); 30 (Rubber and miscellaneous plastics products); 34 ( Fabricated metal products); 35 (Industrial machinery and equipment); 36 (Electrical machinery and equipment); 37 (Transportation equipment); 38 (Instruments and related products); 39 (Miscellaneous manufacturing industries); all 2 digit SIC code under 1 digit SIC code 4 (Transportation, Communication, and Utilities); all 2 digit SIC code under 1 digit SIC code 5 (Wholesale Trade and Retail Trade); all 2 digit SIC code under 1 digit SIC code 6 (Finance, Insurance, and Real Estate); all 2 digit SIC code under 1 digit SIC code 7 and 8 (Service Industries); all 2 digit SIC code under 1 digit SIC code 9 (Public Administration). 


\section{Appendix F - Robustness check results}

Table A.5 - ZINB model for aggregated data, using one period lag for resource dependency

\begin{tabular}{|c|c|c|c|c|c|c|}
\hline \multirow[t]{2}{*}{ "all sectors" } & \multicolumn{3}{|c|}{$\begin{array}{c}\text { Negative Binomial } \\
\text { (Active group) }\end{array}$} & \multicolumn{3}{|c|}{$\begin{array}{c}\text { Logit } \\
\text { (Passive group) }\end{array}$} \\
\hline & coefficie & & $\begin{array}{c}\% \text { change } \\
\text { expected count }\end{array}$ & coefficie & & $\begin{array}{c}\% \text { change odds } \\
\text { ratio }\end{array}$ \\
\hline $\mathrm{Ln}\left(\mathrm{GDP}_{\text {targ. }}\right)$ & $\begin{array}{r}0.647 \\
(0.036)\end{array}$ & $* * *$ & 179.5 & $\begin{array}{r}0.076 \\
(0.115)\end{array}$ & & 12.8 \\
\hline $\operatorname{Ln}\left(G P_{\text {acq. }}\right)$ & $\begin{array}{r}0.365 \\
(0.034)\end{array}$ & $* * *$ & 132.8 & $\begin{array}{l}-1.504 \\
(0.103)\end{array}$ & $* * *$ & -96.9 \\
\hline $\operatorname{Ln}\left(\mathrm{GDPpc}_{\text {targ. }}\right)$ & $\begin{array}{r}0.378 \\
(0.065)\end{array}$ & $* * *$ & 52.3 & $\begin{array}{r}0.529 \\
(0.195)\end{array}$ & $* * *$ & 80.2 \\
\hline $\operatorname{Ln}\left(G_{D P p c} c_{\text {acq. }}\right)$ & $\begin{array}{r}-0.030 \\
(0.101)\end{array}$ & & -4.6 & $\begin{array}{r}-0.893 \\
(0.212)\end{array}$ & $* * *$ & -75.2 \\
\hline $\operatorname{Ln}\left(\right.$ dist $\left._{\text {acq.,targ. }}\right)$ & $\begin{array}{r}-0.674 \\
(0.061)\end{array}$ & $* * *$ & -39.9 & $\begin{array}{r}1.748 \\
(0.171)\end{array}$ & $* * *$ & 274.1 \\
\hline $\begin{array}{l}\text { Resource Dep. } \\
(\mathrm{t}-1)\end{array}$ & $\begin{array}{r}-0.015 \\
(0.005) \\
\end{array}$ & $* * *$ & -13.4 & $\begin{array}{r}0.004 \\
(0.015)\end{array}$ & & 4.1 \\
\hline Transparency targ. & $\begin{array}{r}0.251 \\
(0.022)\end{array}$ & $* * *$ & 38.6 & $\begin{array}{r}-0.065 \\
(0.067)\end{array}$ & & -8.1 \\
\hline Trade open.targ. & $\begin{array}{l}-0.008 \\
(0.002)\end{array}$ & $* * *$ & -16.3 & $\begin{array}{r}0.017 \\
(0.005)\end{array}$ & $* * *$ & 44.5 \\
\hline Financ. open.targ. & $\begin{array}{r}0.009 \\
(0.005)\end{array}$ & $*$ & 6.1 & $\begin{array}{r}-0.012 \\
(0.016)\end{array}$ & & -7.4 \\
\hline Trade open.acq. & $\begin{array}{l}-0.003 \\
(0.001)\end{array}$ & $* * *$ & -11.9 & $\begin{array}{r}-0.022 \\
(0.004)\end{array}$ & $* * *$ & -66.1 \\
\hline Financ. open.acq. & $\begin{array}{r}0.000 \\
(0.000)\end{array}$ & & 4.6 & $\begin{array}{r}0.001 \\
(0.001)\end{array}$ & & 8.1 \\
\hline Wave(global) & $\begin{array}{r}0.001 \\
(0.000)\end{array}$ & $* * *$ & 45.0 & $\begin{array}{r}-0.000 \\
(0.000)\end{array}$ & & -6.8 \\
\hline Com. language & $\begin{array}{r}0.145 \\
(0.106)\end{array}$ & & 15.6 & $\begin{array}{r}-0.783 \\
(0.266)\end{array}$ & $* *$ & -54.3 \\
\hline Colony & $\begin{array}{r}1.357 \\
(0.114) \\
\end{array}$ & $* * *$ & 288.4 & $\begin{array}{r}-1.096 \\
(0.438)\end{array}$ & $* *$ & -66.6 \\
\hline
\end{tabular}

\# of observations: 79,328 \# of nonzero observations: 2,326

$\alpha=1.066$

Vuong test of zinb versus negative binomial: $\quad \mathrm{z}=12.47 \quad \operatorname{Pr}>\mathrm{Z}=0.0000$ LR test of zip versus zinb $\quad \chi$ bar $^{2}=2211.74 \quad \operatorname{Pr}>\chi \mathrm{b}^{2}=0.00$

Notes: Regression includes a constant term and dummies for regions of the acquirer countries and regions of the target countries. Dummies for years are also included in the NBRM. GDPpc = GDP per capita; dist $_{\text {acq.,targ. }}=$ distance between acquirer and target; Resource Dep. $=$ Resource Dependency; Trade open. $=$ trade openness; Financ. open. $=$ financial openness; Com. language $=$ Common language; targ. $=$ target country; acq. = acquirer country. \% chance in expected count (odds ratio) is for standard deviation increase in the variables in question (exception to that is for the two dummy variables, common language and colony, for which we take instead the unit increase in the variable in question). Standard errors are reported in parentheses. $* * *, * *, *$ indicate significance at $1 \%, 5 \%$ and $10 \%$, respectively. The dependent variable is number of cross-border M\&As. 
Table A.6 - ZINB model for M\&As in sectors intensive in natural resources, using one period lag for resource dependency

\begin{tabular}{|c|c|c|c|c|c|}
\hline \multirow[t]{2}{*}{$\begin{array}{l}\text { "Natural } \\
\text { resources" }\end{array}$} & \multicolumn{3}{|c|}{$\begin{array}{l}\text { Negative Binomial } \\
\text { (Active group) }\end{array}$} & \multicolumn{2}{|c|}{$\begin{array}{c}\text { Logit } \\
\text { (Passive group) }\end{array}$} \\
\hline & \multicolumn{2}{|c|}{ coefficient } & $\begin{array}{c}\% \text { change } \\
\text { expected count }\end{array}$ & coefficient & $\begin{array}{c}\% \text { change odds } \\
\text { ratio }\end{array}$ \\
\hline$\overline{\operatorname{Ln}\left(\mathrm{GDP}_{\text {targ. }}\right)}$ & $\begin{array}{c}0.314 \\
(0.127)\end{array}$ & $* *$ & 64.8 & $\begin{array}{c}0.259 \\
(0.363)\end{array}$ & 51.0 \\
\hline $\operatorname{Ln}\left(\mathrm{GDP}_{\text {acq. }}\right)$ & $\begin{array}{l}-0.283 \\
(0.060)\end{array}$ & $* * *$ & -47.6 & $\begin{array}{l}-2.430 \\
(0.195)\end{array}$ & -99.6 \\
\hline $\operatorname{Ln}\left(G D P p c_{\text {targ. }}\right)$ & $\begin{array}{c}0.563 \\
(0.141)\end{array}$ & $* * *$ & 89.5 & $\begin{array}{c}0.356 \\
(0.412)\end{array}$ & 49.8 \\
\hline $\operatorname{Ln}\left(G_{D P p c} c_{\text {acq. }}\right)$ & $\begin{array}{l}0.305 \\
(0.141)\end{array}$ & $* *$ & 61.0 & $\begin{array}{l}-0.472 \\
(0.245)\end{array}$ & -52.1 \\
\hline $\operatorname{Ln}\left(\right.$ dist $\left._{\text {acq.,targ. }}\right)$ & $\begin{array}{l}-0.376 \\
(0.084)\end{array}$ & $* * *$ & -24.7 & $\begin{array}{c}2.280 \\
(0.200)\end{array}$ & 459.6 \\
\hline $\begin{array}{l}\text { Resource Dep. } \\
(\mathrm{t}-1)\end{array}$ & $\begin{array}{l}-0.026 \\
(0.008)\end{array}$ & *** & -22.3 & $\begin{array}{l}-0.008 \\
(0.021)\end{array}$ & -7.3 \\
\hline $\begin{array}{l}\text { Ln(Natural } \\
\text { wealth) }\end{array}$ & $\begin{array}{c}0.140 \\
(0.098)\end{array}$ & & 19.4 & $\begin{array}{l}-0.524 \\
(0.291)\end{array}$ & -48.5 \\
\hline Transparency targ. & $\begin{array}{c}0.136 \\
(0.035)\end{array}$ & *** & 18.8 & $\begin{array}{l}-0.328 \\
(0.114)\end{array}$ & -34.0 \\
\hline Trade open.targ. & $\begin{array}{l}-0.003 \\
(0.003)\end{array}$ & & -5.7 & $\begin{array}{c}0.027 \\
(0.008)\end{array}$ & 81.7 \\
\hline Financ. open.targ. & $\begin{array}{c}0.010 \\
(0.008)\end{array}$ & & 6.4 & $\begin{array}{l}-0.012 \\
(0.022)\end{array}$ & -7.0 \\
\hline Trade open.acq. & $\begin{array}{l}-0.016 \\
(0.002)\end{array}$ & *** & -54.5 & $\begin{array}{l}-0.044 \\
(0.006)\end{array}$ & -88.1 \\
\hline Financ. open.acq. & $\begin{array}{c}0.001 \\
(0.000)\end{array}$ & *** & 15.1 & $\begin{array}{c}0.001 \\
(0.000)\end{array}$ & 22.2 \\
\hline Wave(global) & $\begin{array}{l}-0.000 \\
(0.000)\end{array}$ & & -3.0 & $\begin{array}{l}-0.002 \\
(0.006)\end{array}$ & -38.6 \\
\hline Com. language & $\begin{array}{l}-0.316 \\
(0.140)\end{array}$ & $* *$ & -27.1 & $\begin{array}{l}-0.522 \\
(0.329)\end{array}$ & -40.7 \\
\hline Colony & $\begin{array}{r}1.313 \\
(0.182) \\
\end{array}$ & $* * *$ & 271.7 & $\begin{array}{l}-1.121 \\
(0.712)\end{array}$ & -67.4 \\
\hline $\begin{array}{l}\# \text { of observations } \\
\alpha=0.683\end{array}$ & 4,148 & & & \# of nonzer & oservations: 862 \\
\hline $\begin{array}{l}\text { Vuong test of zint } \\
\text { LR test of zip vers }\end{array}$ & $\begin{array}{l}\text { ersus neg } \\
\text { s zinb }\end{array}$ & r & nial: & $\begin{array}{l}\mathrm{z}=12.19 \\
\chi \text { bar }^{2}=246.9\end{array}$ & $\begin{array}{l}\operatorname{Pr}>z=0.0000 \\
\operatorname{Pr}>\chi b^{2}=0.000\end{array}$ \\
\hline
\end{tabular}

Notes: Regression includes a constant term and dummies for regions of the acquirer countries and regions of the target countries. Dummies for years are also included in the NBRM. GDPpc = GDP per capita; dist $_{\text {acq.,targ. }}=$ distance between acquirer and target; Resource Dep. $=$ Resource Dependency; Trade open. $=$ trade openness; Financ. open. $=$ financial openness; Com. language $=$ Common language; targ. $=$ target country; acq. $=$ acquirer country. $\%$ chance in expected count (odds ratio) is for a standard deviation increase in the variables in question (exception to that is for the two dummy variables, common language and colony, for which we take instead the unit increase in the variable in question). Standard errors are reported in parentheses. $* * *, * *, *$ indicate significance at $1 \%, 5 \%$ and $10 \%$, respectively. The dependent variable is number of cross-border M\&As. 
Table A.7 - ZINB model for M\&As in sectors not intensive in natural resources, using one period lag for resource dependency

\begin{tabular}{|c|c|c|c|c|c|c|}
\hline \multirow[t]{2}{*}{ "other sectors" } & \multicolumn{3}{|c|}{$\begin{array}{c}\text { Negative Binomial } \\
\text { (Active group) }\end{array}$} & \multicolumn{3}{|c|}{$\begin{array}{c}\text { Logit } \\
\text { (Passive group) }\end{array}$} \\
\hline & \multicolumn{2}{|c|}{ coefficient } & $\begin{array}{c}\% \text { change } \\
\text { expected count }\end{array}$ & \multicolumn{2}{|c|}{ coefficient } & $\begin{array}{c}\% \text { change odds } \\
\text { ratio }\end{array}$ \\
\hline $\mathrm{Ln}\left(\mathrm{GDP}_{\text {targ. }}\right)$ & $\begin{array}{c}0.726 \\
(0.041)\end{array}$ & $* * *$ & 217.0 & $\begin{array}{c}0.256 \\
(0.180)\end{array}$ & & 50.1 \\
\hline $\operatorname{Ln}\left(\mathrm{GDP}_{\text {acq. }}\right)$ & $\begin{array}{c}0.707 \\
(0.038)\end{array}$ & $* * *$ & 413.8 & $\begin{array}{l}-1.185 \\
(0.131)\end{array}$ & $* * *$ & -93.6 \\
\hline $\operatorname{Ln}\left(G_{D P p} c_{\text {targ. }}\right)$ & $\begin{array}{c}0.410 \\
(0.073)\end{array}$ & $* * *$ & 57.8 & $\begin{array}{c}0.788 \\
(0.302)\end{array}$ & $* * *$ & 140.5 \\
\hline $\operatorname{Ln}\left(G D P p c_{a c q}\right)$ & $\begin{array}{l}-0.094 \\
(0.113)\end{array}$ & & -13.6 & $\begin{array}{l}-1.057 \\
(0.266)\end{array}$ & $* * *$ & -80.8 \\
\hline $\operatorname{Ln}\left(\right.$ dist $\left._{\text {acq.,targ. }}\right)$ & $\begin{array}{l}-0.991 \\
(0.067)\end{array}$ & $* * *$ & -52.7 & $\begin{array}{c}1.222 \\
(0.215)\end{array}$ & $* * *$ & 151.5 \\
\hline $\begin{array}{l}\text { Resource Dep. } \\
(\mathrm{t}-1)\end{array}$ & $\begin{array}{l}-0.017 \\
(0.006) \\
\end{array}$ & $* * *$ & -15.1 & $\begin{array}{c}0.005 \\
(0.025)\end{array}$ & & 5.0 \\
\hline Transparency & $\begin{array}{c}0.302 \\
(0.024)\end{array}$ & $* * *$ & 48.2 & $\begin{array}{c}0.105 \\
(0.094)\end{array}$ & & 14.6 \\
\hline Trade open.targ. & $\begin{array}{l}-0.014 \\
(0.002)\end{array}$ & $* * *$ & -27.0 & $\begin{array}{c}0.014 \\
(0.007)\end{array}$ & * & 36.8 \\
\hline Financ. open.targ. & $\begin{array}{c}0.015 \\
(0.006)\end{array}$ & $* *$ & 9.9 & $\begin{array}{l}-0.000 \\
(0.024)\end{array}$ & & -0.3 \\
\hline Trade open.acq. & $\begin{array}{c}0.002 \\
(0.001)\end{array}$ & * & 8.5 & $\begin{array}{l}-0.019 \\
(0.005)\end{array}$ & $* * *$ & -60.6 \\
\hline Financ. open.acq. & $\begin{array}{c}0.001 \\
(0.000)\end{array}$ & & 7.6 & $\begin{array}{c}0.001 \\
(0.001)\end{array}$ & & 20.0 \\
\hline Wave(global) & $\begin{array}{c}0.001 \\
(0.000)\end{array}$ & $* * *$ & 50.1 & $\begin{array}{r}-0.000 \\
(0.000)\end{array}$ & & -5.7 \\
\hline Com. language & $\begin{array}{c}0.577 \\
(0.117)\end{array}$ & $* * *$ & 78.1 & $\begin{array}{l}-0.662 \\
(0.384)\end{array}$ & $*$ & -48.4 \\
\hline Colony & $\begin{array}{r}1.164 \\
(0.125) \\
\end{array}$ & $* * *$ & 220.4 & $\begin{array}{l}-1.788 \\
(0.612) \\
\end{array}$ & $* * *$ & -83.3 \\
\hline $\begin{array}{l}\# \text { of observations } \\
\alpha=0.522\end{array}$ & 9,664 & & & $\#$ of nonze & $\mathrm{oob}$ & ervations: 1,379 \\
\hline $\begin{array}{l}\text { Vuong test of zinb } \\
\text { LR test of zip vers }\end{array}$ & $\begin{array}{l}\text { ersus neg } \\
\text { s zinb }\end{array}$ &. & mial: & $\begin{array}{l}\mathrm{z}=7.75 \\
\chi \operatorname{bar}^{2}=562\end{array}$ & & $\begin{array}{l}\operatorname{Pr}>z=0.0000 \\
\operatorname{Pr}>\chi b^{2}=0.000\end{array}$ \\
\hline
\end{tabular}

Notes: Regression includes a constant term and dummies for regions of the acquirer countries and regions of the target countries. Dummies for years are also included in the NBRM. GDPpc = GDP per capita; dist $_{\text {acq,targ. }}=$ distance between acquirer and target; Resource Dep. $=$ Resource Dependency; Trade open. $=$ trade openness; Financ. open. $=$ financial openness; Com. language $=$ Common language; targ. $=$ target country; acq. $=$ acquirer country. $\%$ chance in expected count (odds ratio) is for a standard deviation increase in the variables in question (exception to that is for the two dummy variables, common language and colony, for which we take instead the unit increase in the variable in question). Standard errors are reported in parentheses. $* * *, * *, *$ indicate significance at $1 \%, 5 \%$ and $10 \%$, respectively. The dependent variable is number of cross-border M\&As. 
Table A.8 - ZINB model for M\&As in sectors not intensive in natural resources, controlling for both natural wealth and resource dependency

\begin{tabular}{|c|c|c|c|c|c|c|}
\hline \multirow[t]{2}{*}{ "other sectors" } & \multicolumn{3}{|c|}{$\begin{array}{c}\text { Negative Binomial } \\
\text { (Active group) }\end{array}$} & \multicolumn{3}{|c|}{$\begin{array}{c}\text { Logit } \\
\text { (Passive group) }\end{array}$} \\
\hline & \multicolumn{2}{|c|}{ coefficient } & \multirow{2}{*}{$\begin{array}{c}\begin{array}{c}\% \text { change } \\
\text { expected count }\end{array} \\
\frac{186.2}{}\end{array}$} & \multicolumn{2}{|c|}{ coefficient } & $\begin{array}{c}\% \text { change odds } \\
\text { ratio }\end{array}$ \\
\hline$\overline{L n}\left(G^{\prime} P_{\text {targ. }}\right)$ & $\begin{array}{c}0.659 \\
(0.112)\end{array}$ & $* * *$ & & $\begin{array}{c}0.981 \\
(0.572)\end{array}$ & * & 378.1 \\
\hline $\operatorname{Ln}\left(\mathrm{GDP}_{\text {acq. }}\right)$ & $\begin{array}{c}0.711 \\
(0.038)\end{array}$ & $* * *$ & 406.8 & $\begin{array}{l}-1.251 \\
(0.143)\end{array}$ & $* * *$ & -94.2 \\
\hline $\operatorname{Ln}\left(\mathrm{GDPpc}_{\mathrm{targ}}\right)$ & $\begin{array}{c}0.423 \\
(0.116)\end{array}$ & $* * *$ & 61.4 & $\begin{array}{c}0.244 \\
(0.555)\end{array}$ & & 31.8 \\
\hline $\operatorname{Ln}\left(G_{D P p c} c_{\text {acq. }}\right)$ & $\begin{array}{l}-0.098 \\
(0.111)\end{array}$ & & -14.2 & $\begin{array}{l}-1.104 \\
(0.264)\end{array}$ & $* * *$ & -82.1 \\
\hline $\operatorname{Ln}\left(\right.$ dist $\left._{\text {acq.,targ. }}\right)$ & $\begin{array}{l}-1.020 \\
(0.066)\end{array}$ & $* * *$ & -53.7 & $\begin{array}{c}1.245 \\
(0.220)\end{array}$ & $* * *$ & 156.2 \\
\hline Resource Dep. & $\begin{array}{l}-0.028 \\
(0.007)\end{array}$ & $* * *$ & -23.5 & $\begin{array}{c}0.011 \\
(0.031)\end{array}$ & & 11.3 \\
\hline $\begin{array}{l}\text { Ln(Natural } \\
\text { wealth) }\end{array}$ & $\begin{array}{c}0.049 \\
(0.079)\end{array}$ & & 6.4 & $\begin{array}{l}-0.563 \\
(0.392)\end{array}$ & & -51.1 \\
\hline Transparency targ. & $\begin{array}{c}0.331 \\
(0.025)\end{array}$ & ***; & 52.1 & $\begin{array}{c}0.104 \\
(0.104)\end{array}$ & & 14.1 \\
\hline Trade open.targ. & $\begin{array}{l}-0.017 \\
(0.002)\end{array}$ & $* * *$ & -31.9 & $\begin{array}{c}0.023 \\
(0.008)\end{array}$ & $* * *$ & 67.5 \\
\hline Financ. open.targ. & $\begin{array}{c}0.023 \\
(0.006)\end{array}$ & $* * *$ & 14.8 & $\begin{array}{c}0.010 \\
(0.026)\end{array}$ & & 6.2 \\
\hline Trade open.acq. & $\begin{array}{c}0.002 \\
(0.001)\end{array}$ & $* *$ & 9.7 & $\begin{array}{l}-0.020 \\
(0.005)\end{array}$ & $* * *$ & -63.1 \\
\hline Financ. open.acq. & $\begin{array}{c}0.000 \\
(0.001)\end{array}$ & & 6.9 & $\begin{array}{c}0.001 \\
(0.001)\end{array}$ & & 19.3 \\
\hline Wave(global) & $\begin{array}{c}0.000 \\
(0.000)\end{array}$ & $* *$ & 8.4 & $\begin{array}{c}0.000 \\
(0.000)\end{array}$ & & 10.1 \\
\hline Com. language & $\begin{array}{c}0.589 \\
(0.114)\end{array}$ & $* *$ & 80.3 & $\begin{array}{l}-0.883 \\
(0.388)\end{array}$ & $* *$ & -58.6 \\
\hline Colony & $\begin{array}{l}1.199 \\
(0.124) \\
\end{array}$ & $* * *$ & 231.5 & $\begin{array}{l}-1.601 \\
(0.642) \\
\end{array}$ & $* *$ & -79.8 \\
\hline \multicolumn{4}{|c|}{ \# of observations: 34,171} & \multicolumn{3}{|c|}{$\#$ of nonzero observations: 1,258} \\
\hline \multicolumn{4}{|c|}{$\begin{array}{l}\text { Vuong test of zinb versus negative binomial: } \\
\text { LR test of zip versus zinb }\end{array}$} & $\begin{array}{l}\mathrm{z}=7.86 \\
\chi \operatorname{bar}^{2}=48\end{array}$ & & $\begin{array}{l}\operatorname{Pr}>z=0.0000 \\
\operatorname{Pr}>\chi b^{2}=0.000\end{array}$ \\
\hline
\end{tabular}

Notes: Regression includes a constant term and dummies for regions of the acquirer countries and regions of the target countries. Dummies for years are also included in the NBRM. GDPpc = GDP per capita; dist $_{\text {acq.,targ. }}=$ distance between acquirer and target; Trade open. $=$ trade openness; Financ. open. $=$ financial openness; Com. language $=$ Common language; targ. $=$ target country; acq. $=$ acquirer country. $\%$ chance in expected count (odds ratio) is for a standard deviation increase in the variables in question (exception to that is for the two dummy variables, common language and colony, for which we take instead the unit increase in the variable in question). Standard errors are reported in parentheses. $* * *, * *, *$ indicate significance at $1 \%, 5 \%$ and $10 \%$, respectively. The dependent variable is number of cross-border M\&As. 
Table A.9 - ZINB model for M\&As in sectors not intensive in natural resources controlling for alternative measure of resource dependency

\begin{tabular}{|c|c|c|c|c|c|c|}
\hline \multirow[t]{2}{*}{ "other sectors" } & \multicolumn{3}{|c|}{$\begin{array}{c}\text { Negative Binomial } \\
\text { (Active group) }\end{array}$} & \multicolumn{3}{|c|}{$\begin{array}{c}\text { Logit } \\
\text { (Passive group) }\end{array}$} \\
\hline & coefficie & & $\begin{array}{c}\% \text { change } \\
\text { expected count }\end{array}$ & coefficie & & $\begin{array}{l}\text { \% change } \\
\text { odds ratio }\end{array}$ \\
\hline$\overline{\mathrm{Ln}\left(\mathrm{GDP}_{\text {targ. }}\right)}$ & $\begin{array}{r}0.780 \\
(0.40)\end{array}$ & $* * *$ & 239.6 & $\begin{array}{r}0.173 \\
(0.176)\end{array}$ & & 31.1 \\
\hline $\operatorname{Ln}\left(\mathrm{GDP}_{\mathrm{acq}}\right)$ & $\begin{array}{r}0.713 \\
(0.038)\end{array}$ & $* * *$ & 408.6 & $\begin{array}{r}-1.180 \\
(0.144)\end{array}$ & $* * *$ & -93.2 \\
\hline $\mathrm{Ln}\left(\mathrm{GDPpc}_{\text {targ. }}\right)$ & $\begin{array}{r}0.315 \\
(0.081)\end{array}$ & $* * *$ & 42.7 & $\begin{array}{r}0.821 \\
(0.349)\end{array}$ & $* * *$ & 153.2 \\
\hline $\operatorname{Ln}\left(G^{\prime} P p c_{\text {acq. }}\right)$ & $\begin{array}{r}-0.120 \\
(0.117)\end{array}$ & & -17.1 & $\begin{array}{r}-1.197 \\
(0.275)\end{array}$ & $* * *$ & -84.6 \\
\hline $\operatorname{Ln}\left(\right.$ dist $\left._{\text {acq.,targ. }}\right)$ & $\begin{array}{r}-1.010 \\
(0.071)\end{array}$ & $* * *$ & -53.5 & $\begin{array}{r}1.206 \\
(0.239)\end{array}$ & $* * *$ & 149.3 \\
\hline Nat. Wth. Dep. & $\begin{array}{r}-0.003 \\
(0.002)\end{array}$ & $*$ & -15.3 & $\begin{array}{r}-0.007 \\
(0.010)\end{array}$ & & -33.2 \\
\hline Transparency targ. & $\begin{array}{r}0.329 \\
(0.026)\end{array}$ & $* * *$ & 51.4 & $\begin{array}{r}0.067 \\
(0.101)\end{array}$ & & 8.9 \\
\hline Trade open.targ. & $\begin{array}{r}-0.020 \\
(0.002)\end{array}$ & $* * *$ & -38.5 & $\begin{array}{r}0.017 \\
(0.007)\end{array}$ & $* *$ & 50.7 \\
\hline Financ. open.targ. & $\begin{array}{r}0.014 \\
(0.006)\end{array}$ & $* *$ & 10.0 & $\begin{array}{r}-0.006 \\
(0.023)\end{array}$ & & -4.1 \\
\hline Trade open.acq. & $\begin{array}{r}0.002 \\
(0.001)\end{array}$ & $* *$ & 11.6 & $\begin{array}{r}-0.018 \\
(0.005)\end{array}$ & $* * *$ & -57.7 \\
\hline Financ. open.acq. & $\begin{array}{r}0.000 \\
(0.000)\end{array}$ & & 7.5 & $\begin{array}{r}0.001 \\
(0.001)\end{array}$ & & 20.7 \\
\hline Wave(global) & $\begin{array}{r}0.000 \\
(0.000)\end{array}$ & $* *$ & 8.6 & $\begin{array}{r}0.001 \\
(0.001)\end{array}$ & & 14.3 \\
\hline Com. language & $\begin{array}{r}0.612 \\
(0.120)\end{array}$ & $* * *$ & 84.3 & $\begin{array}{r}-0.780 \\
(0.416)\end{array}$ & * & -54.2 \\
\hline Colony & $\begin{array}{r}1.176 \\
(0.125) \\
\end{array}$ & $* * *$ & 224.2 & $\begin{array}{r}-1.708 \\
(0.946) \\
\end{array}$ & $* * *$ & -81.9 \\
\hline
\end{tabular}

\# of observations: 37,222 \# of nonzero observations: 1,275 $\alpha=0.487$

Vuong test of zinb versus negative binomial: $\quad \mathrm{z}=7.98 \quad \operatorname{Pr}>\mathrm{z}=0.0000$ $\begin{array}{lll}\text { LR test of zip versus zinb } \quad \chi \text { bar }^{2}=495.88 & \operatorname{Pr}>\chi \mathrm{b}^{2}=0.00\end{array}$

Notes: Regression includes a constant term and dummies for regions of the acquirer countries and regions of the target countries. Dummies for years are also included in the NBRM. GDPpc = GDP per capita; dist $_{\text {acq.targ. }}=$ distance between acquirer and target; Nat. Wth Dep. = Natural Wealth Dependency; Trade open. $=$ trade openness; Financ. open. $=$ financial openness; Com. language $=$ Common language; targ. $=$ target country; acq. = acquirer country. \% chance in expected count (odds ratio) is for standard deviation increase in the variables in question (exception to that is for the two dummy variables, common language and colony, for which we take instead the unit increase in the variable in question). Standard errors are reported in parentheses. $* * *, * *, *$ indicate significance at $1 \%, 5 \%$ and $10 \%$, respectively. The dependent variable is number of cross-border M\&As. 